\title{
URBAN EVOLUTION OF THE CITY OF DOHA: AN INVESTIGATION INTO THE IMPACT OF ECONOMIC TRANSFORMATIONS ON URBAN STRUCTURES
}

\author{
Florian WIEDMANN*, Ashraf M. SALAMA**, \\ Alain THIERSTEIN***
}

Received: 19.12.2011; Final Text: 28.04.2012

Keywords: Doha; Gulf; urbanisation; economic diversification; urban structure; knowledge economies.
* Qatar University, Doha, QATAR.

** Department of Architecture and Urban Planning, Qatar University, Doha, QATAR.

*** Department of Architecture, Munich University of Technology, Munich, GERMANY.
During the second half of the 20th century Qatar has witnessed its first urbanisation period, which was linked to the rapidly increasing oil production. Today, new development strategies, which have been implemented to diversify its economy, have led to a second urban transformation process. Concomitantly, Doha has witnessed its rise from being a small fishing village community in the middle of the 20th century to an emerging regional urban centre with more than 1.5 million inhabitants. This paper offers an exploratory analysis of the urban evolution of Qatar's capital city Doha based on Henri Lefèbvre's theory of space production. The paper explores different stages of economic transformation that have had a large impact on the structure of the city's society as well as its built environment. It also analyses, the most recent transformation process that began at the end of 20th century as a result of a rapidly growing real estate development generated by liberalisation policies and public investments. In order to understand the future impact of current economic development strategies, the city's past urbanisation stages and their spatial development factors are outlined through different periods - from the pre-oil settlement, to oil production, to liberalization and economic diversification strategies. The analysis of different stages manifests that each urbanization period was driven by a specific economic activity and was based on key governance and planning strategy with a particular impact on the urban structure and architecture. The paper concludes by relating the evolutionary process of the city to the challenges facing its future urban environment so that responsive strategies for liveability and quality of urban life can be envisioned and implemented.

\section{INTRODUCTION: LEFÈBVRE AND THE EVOLUTION OF URBAN SPACE}

Diverse factors produce urban space including economic, social and environmental circumstances. These factors accumulate in cities, where 
1. Henry Lefèbvre (1905-1991) was a Marxist philosopher and a dynamic intellectual. Throughout his career, he maintained a strong commitment to Marxism, but has also criticized it as being too dogmatic (Merrifield 2006; Shields, 1999). The English translations of his books during the 1990s and early 2000s corroborate the appreciation and value of his work in contemporary discourse. His ideas and theories were centred on dialectical thinking, notions of critique, and the meaning and politics of space and society. While he was a multifaceted thinker, the focus of this paper is on the factors he identified as integral components in the process of space production. While very valuable in the fields of city politics and social sciences, a discussion of other aspects of his work would go beyond the scope of this paper. they result in visible urban morphologies. Any urban space is thus the product of the economic and cultural interactions of a society as determined by its natural response to its environment. Over the centuries these interactions have undergone an evolutionary process derived from a gradual increase of knowledge, which constitutes the basis for progress within the development of a civilisation. While in pre-industrial times space was the direct result of simple interactions geared toward sustaining life, the more technologies were invented the more centralised and planned urban structures became. Parallel to this development, populations were less and less able to participate in the production of space as urban structures became a reflection of the will of political and economic powers. Cities then underwent a new period of transformation during the second half of the 20th century after they had become industrialised in which new technologies allowed for development of regional and global networks (Witlox, Derudder, 2007, 36).

As a result of these new networks, international hubs came into being on the basis of attracting companies in the advanced service sectors and their headquarters. The main resource of these new economies is human knowledge and thus they are often referred to as knowledge economies. Today, there is fierce competition between established global centres and new emerging cities worldwide (Gaebe, 2004, 33). Thus, the quality of urban space is gaining importance due to the necessity of attracting and sustaining human resources. In this context, this paper seeks to substantiate the hypothesis that urban governance in emerging cities is increasingly facing the crucial need for integrating the specific requirements of growing knowledge communities. The basis of the analysis of urban evolution in the emerging city of Doha is the work of the French sociologist Henri Lefebvre, who is known for his comprehensive theories on the production of space (Lefèbvre, 1991)(1).

Lefèbvre defines three main factors in the process of space production, namely, conceived space, perceived space and lived space. While conceived space is regarded as the space produced by planners and political decision-makers, and is therefore based on knowledge and ideologies, perceived space is produced by the spatial practice of all the users of a space. In addition to movements (habitus) and planning (intellectus) space is formed by the invisible degree of people's attachment to a certain place. This subjective dimension of space production is defined as lived space (intuitus). Based on his theory of the three dimensions that produce space, Lefèbvre developed his second ontological transformation of space in order to address the evolutionary dimension through the course of history (Figure 1). While in the past spatial practice was initially the dominant factor in the production of space, a period followed in which conceived space became most influential. The end of the 20th century though marks, in Lefèbvre's view, the beginning of a new type of space that is more dominated by lived space and which he considers as still being in its infancy. He names these three historical phases as 'absolute space', 'abstract space' and 'differential space' (Lefèbvre, 1991, 353).

Absolute space was the result of humans' spatial practice, namely, their physical interaction with the natural environment, driven by the need for survival. This absolute space is more or less free of intellectual intervention and rationalised planning (Lefèbvre, 1991, 230). It should be seen as a product resulting from the common effort of every single member of a society and therefore as a direct reflection of traditions and environmental 


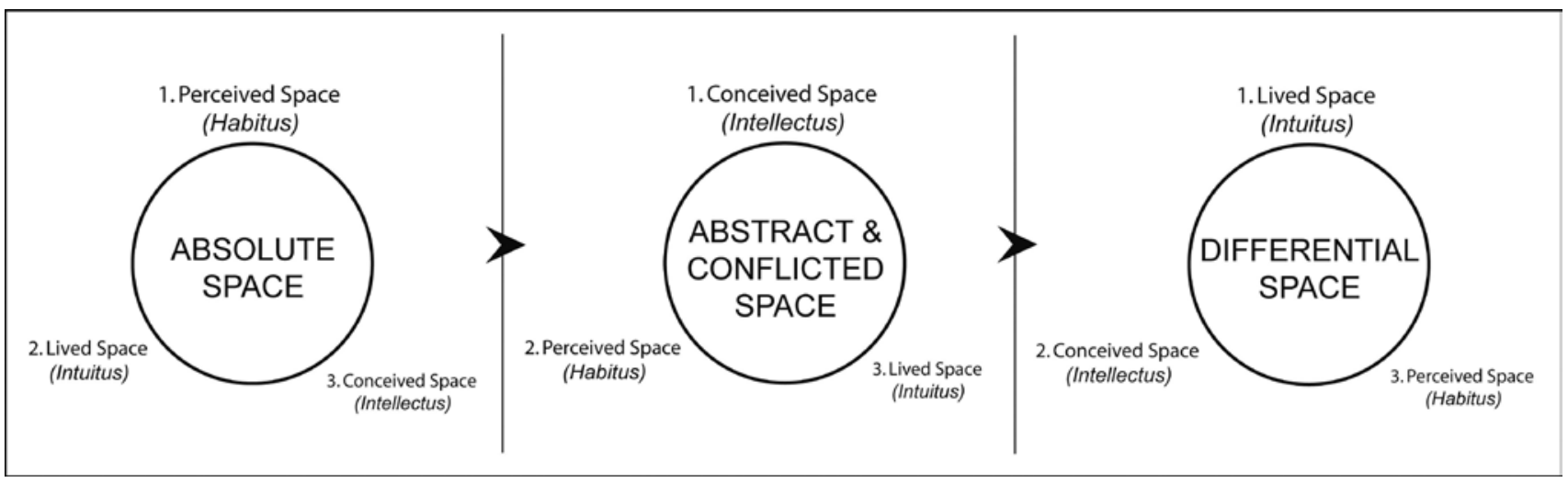

Figure 1. Model of Lefèbvre's theory of space production and evolution. Source: Authors. circumstances. According to Lefèbvre's interpretation the Greek and Roman antiquity, in which countryside and urban settlements were not understood as contrasted but rather seen as merged, constitute the time period of absolute space in Europe (Lefèbvre, 1991, 247). Absolute space as the predominant space in European history ended together with the feudal system at the time that a capital-driven economy was beginning to emerge during the 12th century (Lefèbvre, 1991, 255). The epoch of the Renaissance came into being through expanding commerce, causing the end of the unity of country and city. Due to the increasing development of trade routes and rapid population growth, cities became market centres and thus places where wealth and subsequently knowledge accumulated (Lefèbvre, 1991, 262). The city became the centre of political power and its spatial development became more and more administered and shaped by its rulers to enhance the functionality of its urban space. Conceived space, the space of the intellect, began to emerge and formed a new type, known as 'abstract space', named for its characteristic of reducing the spatial aspects into functional and geometrical forms (Lefèbvre, 1991, 361).

The gradual transition from absolute space to abstract space was, in the case of Europe, a rather extensive period stretching from its first roots in late antiquity through to the rise of national states and the beginnings of industrialisation to contemporary urban space. The industrialisation period marked a significant step within this evolutionary process since it demanded planning on various scales and in various areas (Lefèbvre, 1991, 341). Urban planning became an important tool for shaping urban structures by defining road networks and land use. The functional subdivision of land into residential areas, business areas, and industrial areas has been the consequence of expanding public administration. The introduction of the car as a new mode of transport during the 20th century marked another milestone in the development of urban space by making distances between the various functional spaces manageable, thus giving rise to suburban sprawl. Particularly after World War II urban planning was often reduced to the calculation and implementation of physical plans that enabled cities to be accessible by car (Lefèbvre, 1991, 359). The end of the 20th century can be seen as the beginning of a new transition period, which is called 'conflicted space'. The dominant role of conceived space within abstract space leads to the rise of increasing conflicts. The dependency on the factor of growth has become inhibiting for the emergence and sustenance of urban qualities (Lefèbvre, 1991, 354).

The commercialisation of space has created fragmented and segregated urban landscapes, which are described by Lefèbvre as agglomerations 
2. Major cities in the Gulf region have recently acquired a geo-strategic importance. Through the shift of global economic forces cities in the region, and Doha is no exception, are developed as central hubs between old economies of Western Europe and the rising economies of Asia. In the context of international competition between cities new challenges are emerging where cities need to find ways to sustain and extend their position in the context of a global knowledge economy. Knowledge based economies have been identified as the key driver for spatial and urban development processes. They include services, high tech industries, and higher education institutions, and are characterized by strong international presence and transnational practices. A considerable number of studies and research projects have been conducted and are being conducted to address timely and pressing issues relevant to major cities of the region (Thierstein and Schein, 2008; Scharfenort, 2009; Wiedmann, 2010; Salama and Theirstein, 2010; Alawady, 2011). In essence, they attempt to answer questions related to the qualities of urbanism and the way in which cities can survive in the global competition of geographic locations while influencing their significance within a knowledge economy context. consisting of either 'spaces of leisure' or 'spaces of labour' (Lefèbvre, 1991,383 ) where the role of inhabitants is largely reduced to either the consumption of space or the production of goods and services (Lefèbvre, 1991, 353). However, the basis for this type of 'conflicted space,' is being eroded by the emergence of knowledge economies. Knowledge has become more an influential factor within economic development by appreciating the importance of a qualified workforce and so their particular needs and demands with regard to space. Thus, urban diversity and urban identity are becoming more decisive in terms of the economic sustainability of cities, which is why Lefèbvre predicts 'lived space' to become an increasingly significant factor in the future in the production of urban space (Lefèbvre, 1991, 399). In such a scenario, individual long-term investment on the part of the members of a coherent society will overcome the shortterm interests of speculators and the self-management of urban cells will replace top-down and technocratic decision-making. Lefèbvre argues that urban qualities are highly dependent on the proactive participation of an enlightened society, creating a diverse urban space, or as he puts it - a 'differential space' (Lefèbvre, 1991, 52).

While Lefèbvre's work focused on European urban history, his theory of space evolution is applicable to a wide variety of contexts. In many parts of the world there is rather little reflection about contemporary urbanism in relation to its complex contexts and their evolution overtime. The emerging cities in the Gulf are extreme cases in which the history of urban evolution is reduced to a time period of a few decades. The production of oil and the liberalisation strategies of the last two decades are the key forces driving the modern urbanisation process in the Gulf. In this paper the urban evolution of Qatar's capital Doha is investigated by examining each of its four distinct urban spaces during its rapid urban development from a pre-oil settlement to an oil city and then its transformation to an emerging service centre within regional and global networks (2).

\section{ABSOLUTE SPACE: THE VERNACULAR PRE-OIL SETTLEMENTS OF DOHA}

During the 18th century the Al Maadhid tribe and its leading family clan Al Thani moved from central Arabia to settle on the northern coast of Qatar, where they resided in the area around Zubara. As a consequence of tribal conflicts with the $\mathrm{Al}$ Khalifa tribe the $\mathrm{Al}$ Maadhid tribe under the leadership of Sheikh Mohammed bin Thani resettled on the eastern coast of the Peninsula in 1847, where its clans founded the settlement of Al Bidaa at the location of an old fishing village (Adham, 2008, 221). The choice of location was based on the water source Wadi Sail and the fortunate shape of the coastline, which protected the settlement from sea attacks. When the expanding pearl trade led to on-going conflicts with the Al Khalifa tribe, the British colonial power was concerned about the maritime security of its trading routes and signed a contract in 1868 with the Al Thani clan recognising its official rulership of Qatar. During the first decades of the 20th century Al Bidaa grew to around 12,000 inhabitants due to the flourishing pearl trade. However, its population rapidly decreased during the 30s, when Qatar's entire population dropped from 27,000 to less than 16,000 inhabitants because of the collapse of pearl fishing caused by the invention of cultured pearls in Japan (Al Buainain, 1999, 149).

The development of Al Bidaa into eight distinct settlements along the shoreline, which together occupied an area of around $1.23 \mathrm{sq} \mathrm{km}$ (Hasan, 
Figure 2a. The traditional urban structure of old Doha. Source: Msheireb Properties.

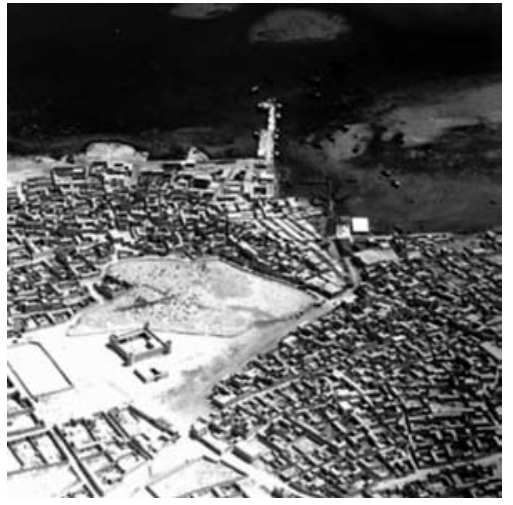

Figure $\mathbf{2 b}$. The old urban fabric of Doha. Source: Msheireb Properties.

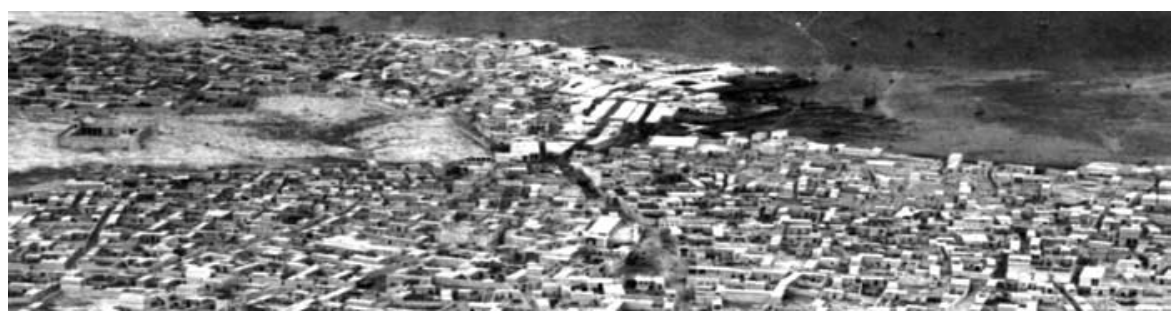

1994), was a result of the need for access to the sea, land distribution to tribal clans and the location of water sources. Al Bidaa was later renamed Doha, which either refers to a big tree standing at the coast or to the circular shape of the coastline (Al Buainain, 1999, 181). Doha's population during the first half of the 20th century consisted of the Al Maadhid tribe in addition to groups of Persian immigrants, who were mainly engaged as craftsmen in boat construction, and East-African slaves working as fishermen or in the pearl industry. Furthermore, Bedouin tribes settled in tents and barasti huts at the periphery of Doha during certain seasons in order to trade their animals and animal products (Adham, 2008, 224). Each social group lived segregated in their own areas and the main centres of social interaction were the harbour, market and mosque. While the residential districts of the $\mathrm{Al}$ Maadhid tribe were mainly located within the small separate settlements in the east and west of Al Bidaa, Persians and other Arab immigrants lived close to the market and harbour area, currently known as Al Jasrah (Al Buainain, 1999, 190). Due to the socioeconomic importance of the market and harbour area each neighbourhood was directly linked via roads. However, the road network was not a result of conscious planning but rather the consequence of the collective building efforts of each family. The ruler's function concerning the administration of the settlement development was limited to incentives regarding where to build a palace and mosque in addition to a macro-distribution of land regarding markets and new residential districts. Furthermore, within the tribal structure he was seen as the leading sheikh and thus as executor of Islamic law, which also covered building violations (Hakim, 2007, 154). However, most construction concerns were dealt with at lower levels within tribal clans and thus it can be stated that Doha's settlement development was mainly governed by bottom-up rather than top-down decision-making.

Homes were built based on the inherited knowledge of the indigenous population using local building materials such as palm fronds and trunks as well as coral, stones and mud. Residential buildings varied from simple buildings with one space and entrance to courtyard houses with two floors (Jaidah and Bourenane, 2009, 30). The design followed the Islamic tradition of dividing male and female spaces and the high degree of family privacy, which was further mirrored in the complex system of winding alleys within neighbourhoods that served as access to individual homes (Jaidah and Bourenane, 2009, 22). In these neighbourhoods, known as ferej, each family clan built their homes in close proximity to each other, usually wall on wall, due to their strong affiliation and social interaction. The high density of the built area was also influenced by the hot climate and the necessity to shade walkways and exposed walls. The souq itself was partly roofed and located at the end of Wadi Sail. As in other Islamic port cities Doha's market stretched in linear fashion along main roads and side roads from the harbour area toward inland. The town centre was marked 

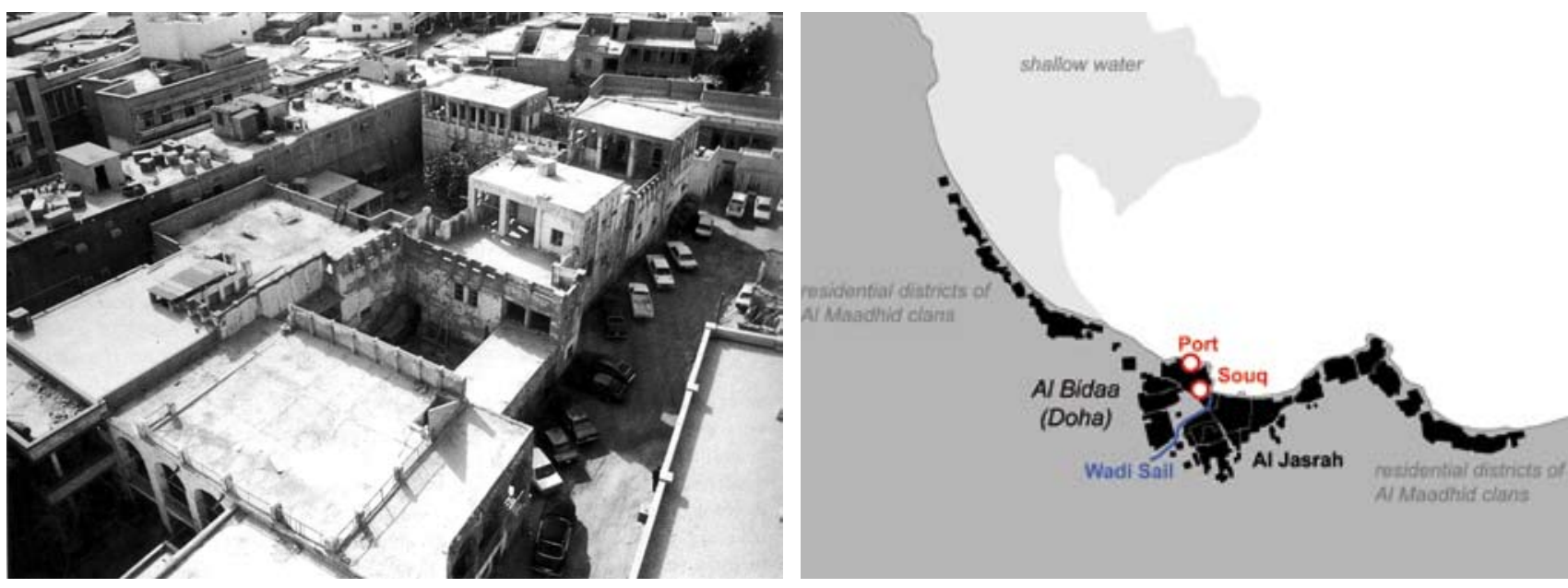

Figure 2c. A traditional cluster of houses in old Doha. Source: Msheireb Properties.

Figure 2d. Doha's pre-oil settlements in 1947. Source: Authors. by the Friday mosque and the palace. The end of the souq in the south was marked by the $\mathrm{Al}$ Khoot Fort, surrounded by the large open space of the cemetery (Figure 2a, 2b).

Doha's traditional urban form remained intact until the middle of the 20th century when modern urbanisation began. Its vernacular structure and architecture were the result of direct human interaction and participation within the building process. Climate and culture had thus shaped a built environment reflecting not only how its spaces were used from a functional point of view but also how these spaces expressed the inner world of a society that was highly dependent on its natural environment and tribal affiliations (Figure 2c). The former was reflected in structural aspects of the local architecture that were adapted to the desert climate while the latter was reflected in decorative elements such as plant images or geometric patterns on walls and doors indicative of the people's tribal origins in central Arabia. Both advanced building techniques and the conservation of traditional façade decoration convey the old roots of Doha's historic built structures.

Although the settlement was founded as a small fishing village at the beginning of the 19th century and thus looks back on a rather short history, its urban and architectural forms are thousands of years old (Al Buainain, 1999, 186). Inherited knowledge and traditions have built this space by following no planning or centralised regulations. Despite the allocation of land by tribal rulers, land was generally free to use and build on. Thus, organic settlement patterns evolved based on the principle of a cell, in this case the courtyard house, multiplying into clusters to form neighbourhoods that connected to the central backbone of the settlement - the market, port and mosque (Figure 2d). Doha's pre-oil settlement is to a large extent the product of the collective efforts of its inhabitants, their habits and their intuition and thus it is interpreted as an "absolute space". Capitalist incentives caused by the pearl trade or the interaction with colonial powers had not yet led to centralised planning and state regulations impacting Doha's vernacular structure. 


\section{ABSTRACT SPACE: MODERN URBANISATION AS A RESULT OF THE OIL BOOM}

Although oil had already been found by Petroleum Development Qatar Ltd. in Dukhan in the west of the country in 1937, production began after World War II at the time of Qatar's modern urbanisation (Scholz, 1999, 188). The first revenues made from oil were mainly invested in the development of infrastructure such as the construction of a regional road connecting the Dukhan field with Doha and the first airport, which was built in the east of the city. Due to the location of the residence of the ruling Al Thani family, Doha became the centre of modern urbanisation in Qatar. From the 1950s to 1970 Doha's population grew from around just 14,000 inhabitants to over 83,000, with foreign immigrants constituting about 67\% (Al Buainain, 1999, 217). Almost 90\% of the working population was non-Qatari in 1970 due to a lack of educated workforce among the indigenous population and the introduction of subsidies, which turned Qatar into a classic welfare state reliant on its fossil resources. Nation-wide only about $25 \%$ of around 30,000 Qataris were counted as workforce by a census in 1970 and most were engaged in the newly established public administration in Doha (Al Buainain, 1999, 168). The private sector was mainly run by immigrants from South Asia and other Arab countries, who worked in the expanding trade businesses or as employees in the lower service sector.

During the 1950s and 1960s settlement patterns were determined by the development of modern infrastructure such as roads and the supply of fresh water and electricity. The modern administration, which was distributed among various buildings all over the city, was just in its infancy and despite the introduction of the first public housing law in 1964, planning and regulations still had limited impact on the general

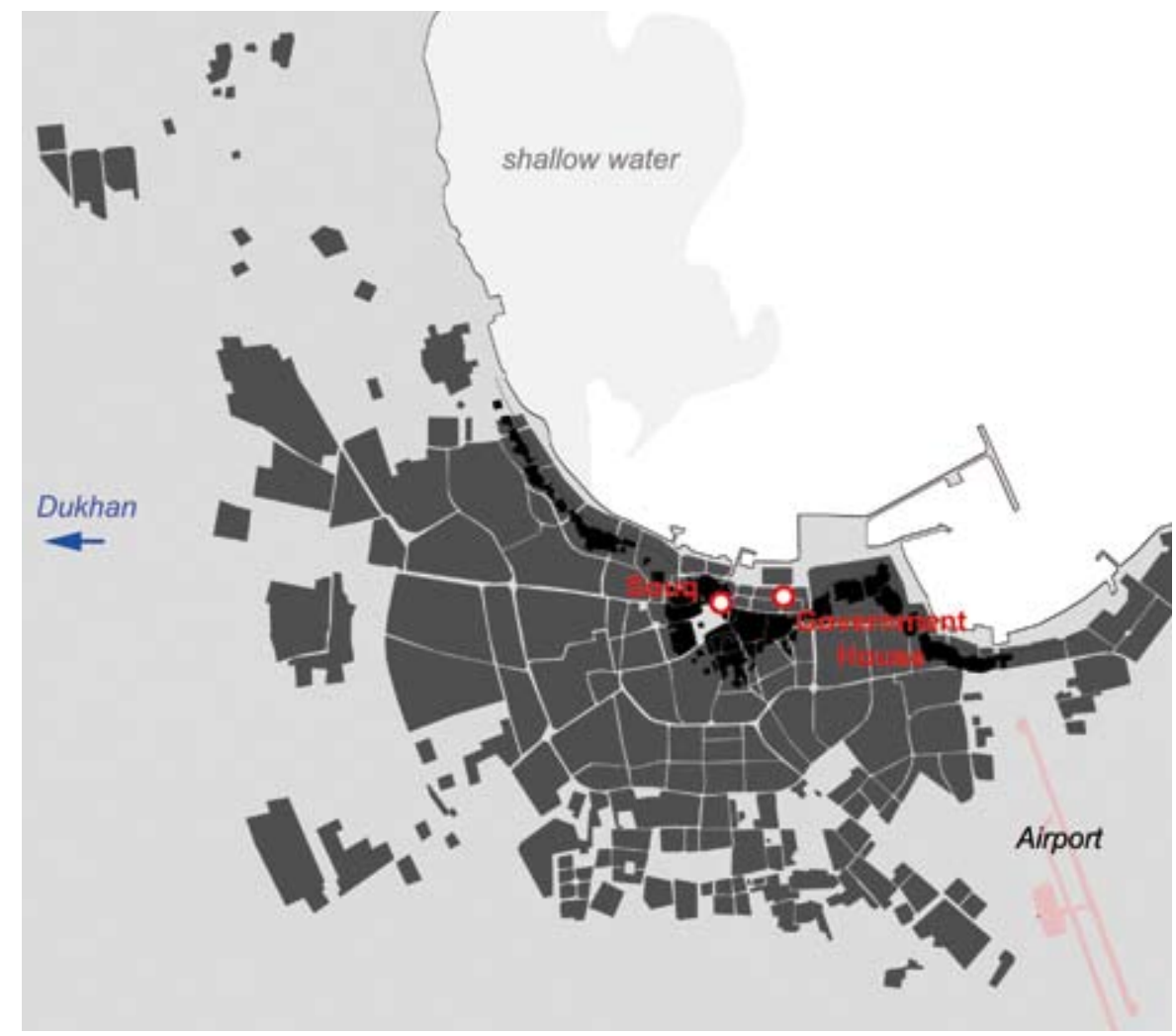


development (Al Buainain, 1999, 192). Yet, a major impact was made on the urban form by imported goods, particularly cars and air conditioning, and the vast immigration. Subsequently, roads were widened in central areas to provide access by car and the old courtyard buildings were replaced by modern building blocks made of cement stones. Furthermore, new housing areas were constructed in a rather uncoordinated manner around the former city boundaries in order to accommodate expatriate labour as well as Qataris moving from other parts of the country to Doha. Subsequently, the city grew in all directions with development mainly concentrated in the west because of the road to Al Dukhan and south-east toward the airport (Figure 3). Due to the rapidly growing trade of imported goods many informal shopping areas grew along the periphery of the city centre and in proximity to the old market area (Scholz, 1999, 201).

In this first period of Doha's urban transformation developments were generally rather uncoordinated. However, incentives such as the reclamation of an area at Doha's port or the construction of the Al-Corniche Road would become elements that defined later urban developments. Rectangular settlement patterns and modern cement buildings added a fragmented belt around the old centre and its harbour, which in turn were gradually replaced by modern urbanisation. Thus, Doha's traditional urban space faced its rapid end, caused by the first investments in modern infrastructure and the increasing purchasing power of its population. Subsequently, cars and air conditioning enabled the emergence of a new urban structure with low built densities, extensive road grids and cement block architecture.

While an initial public administration already existed in the 1950s and grew during the 1960s when the first municipality was founded in 1963, it was only after the declaration of Qatar's independence as a state in 1971 and, perhaps even more significantly, when Sheikh Khalifa Bin Hamad Al Thani took over as ruler in 1972 that an efficient central administration came into being (Zahlan, 1979). This administration included several ministries that dealt with Qatar's urbanisation, the most important of which was the Ministry of Municipal Affairs and Agriculture (MMAA) with its town planning section established in 1974 (Al Buainain, 1999, 207). It was later followed by the creation of several ministries that dealt with infrastructural development such as the Ministry of Public Works (MPW). The centralisation of governance enabled petrodollars to be efficiently invested in the urbanisation process, leading to rapid urban growth during the 1970s and 1980s when oil prices reached new heights.

During this period, many Western consultants were involved in the first phase of urban planning in Doha. In 1974 the British consultant Llewelyn Davis was appointed by the new town planning authority within the MMAA to design the first masterplan of Doha for 1990. His plan was based on a ring concept with a clear definition and a functional distribution of land uses regarding each ring. This basic structure was the basis for the development of a ring-road system during the 1970s as well as for subsequent land allocation and suburban sprawl in the outskirts of Doha. Based on this initial zoning plan and newly introduced land policies a new city centre was created consisting of commercial developments, services and multi-storey housing. During the 1970s all old Qatari neighbourhoods were replaced and the indigenous population moved to new suburban developments such as Al Rayyan, Medinat Khalifa or Al Gharrafa in the north-west of the city. This was made possible by the land policies, which 
included the free replacement of properties with allocated plots of land measuring $30 \times 30$ metres and the provision of interest-free loans for the construction of housing or financial compensation, which usually exceeded the market price of real estate at that time (Naqy, 1997).

Subsequently, the 1970s witnessed increasing land speculation within the city centre and its surrounding areas. Until 1991 the Planning Department of the MMAA was in charge of subdividing land into parcels while public housing programmes were the domain of the Ministry of Labour and Social Affairs as well as the Ministry of Public Works. These superposed responsibilities led to coordination problems, which were further exacerbated by the fact that high-profile projects were usually under the supervision of the Emiri Diwan and thus not part of the general legalisation process within ministries (Al Buainain, 1999, 203). Despite these debilitating factors the main elements of Doha's first master plan were implemented and its proposed land reclamation of 630 hectares in the north of the city centre, which included the development of a circular Corniche, was completed at the end of the 1970s (Scholz, 1999, 202). The main objective of the plan was, however, to establish a modern city centre. For this purpose, informal commercial building was no longer possible and

Figure 4a. Qatar University campus: original master plan incorporated as part of the development of North District of Doha. Source: Qatar University's Business Operations Department.

Figure $4 \mathrm{~b}$. Main administration building of Qatar University. Source: Authors.

Figure 4c. A typical educational cluster, Qatar University. Source: Authors.
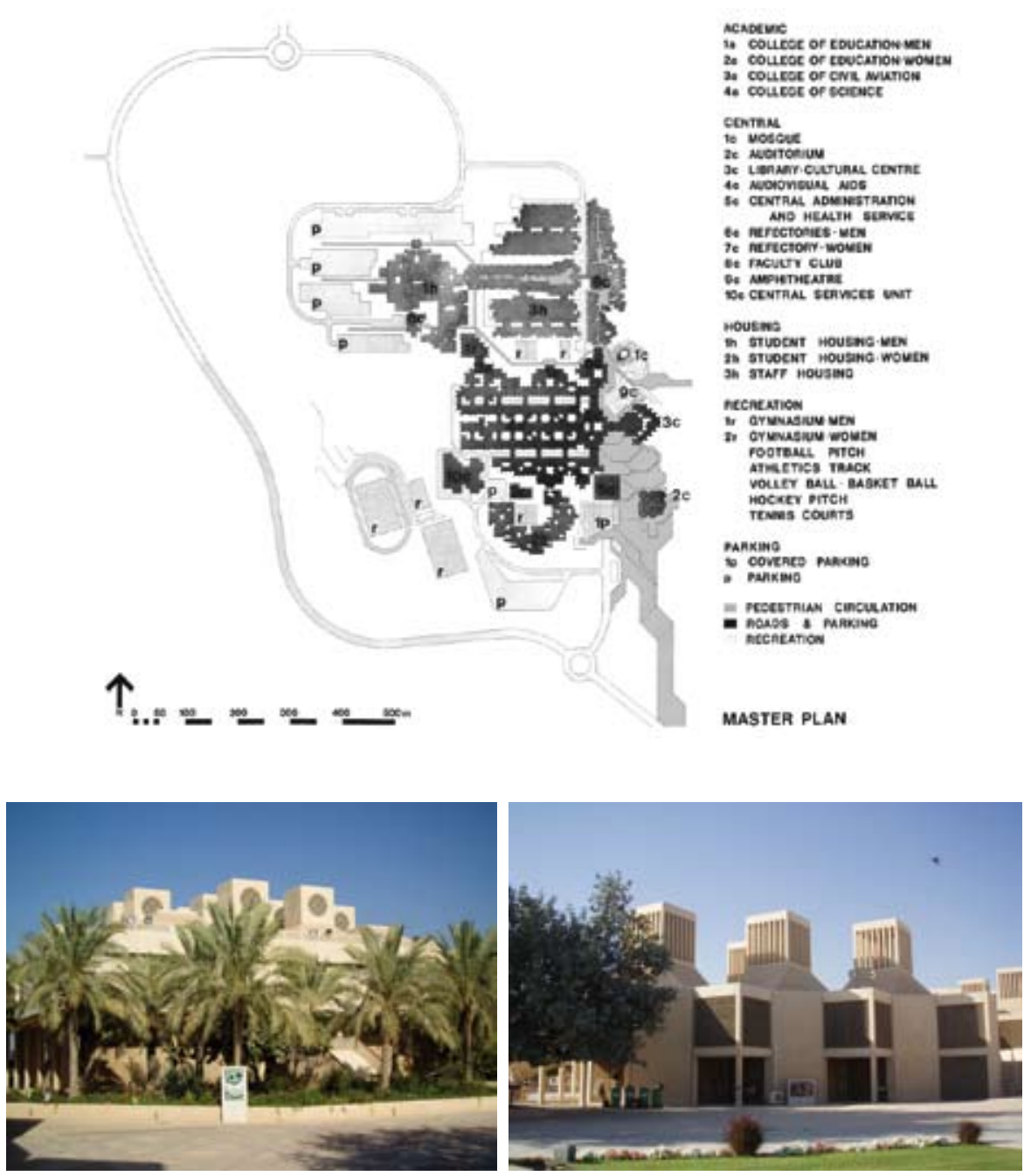
traditional buildings were replaced in order to make space for access roads and multi-storey developments.

While Llewelyn Davis continued his planning efforts regarding the city centre until 1977, the American planning consultancy William L. Pereira Associates was commissioned in 1975 to develop in parallel a new masterplan for an extension area in the north, known as North District of Doha (NDOD) or West Bay (Adham, 2008, 233). The plan included the development of Qatar University and housing for its staff as well as residential districts toward inland (Figure $4 a, 4 b, 4 c$ ). With regard to coastal development at the northern end of the Corniche, it proposed a large hotel development for conferences, a diplomatic and ministries area and a new business district surrounded by a large park (Naqy, 2000, 137). While the hotel development and several embassies were completed during the beginning of the 1980s, the commercial centres remained to a large extent un-built due to the focus of commercial activities in and around the city centre. At the same time as the NDOD was initially being developed in the early 1980s, consultants were engaged to review and adjust the zoning plan for existing urban areas in order to accommodate the unexpected population growth and improve the built environment in the city centre. In 1985 the Lebanese company, Dar Al Handaseh Consultants, was assigned to conduct detailed surveys of Doha's city centre and to create a list of possible interventions to increase urban qualities (Dar Al Handaseh, 1986). However, the majority of these plans had a minor effect on the actual urban development.

While in the transition period during the 1950s and 1960s old traditional structures were gradually replaced by a rather uncoordinated process of modernisation, the implementation of a first masterplan and the city extension via land reclamation were decisive steps in Doha's modern urbanisation, carried out by a newly established public administration during the 1970s. Subsequently, the population of Doha's metropolitan area grew from 89,000 inhabitants in 1970 to over 434,000 in 1997. In addition to this rapid growth, land policies and real-estate speculation caused the total urban area to increase exponentially from around just 130 hectares in the middle of the 20th century to over 7,100 hectares in 1995 (Al Buainain, 1999, 407). The urban sprawl during the oil boom led to a scattered urban landscape with low densities, caused by the prevalence of suburban typologies and a large percentage of un-built land due to speculation (MMAA, 1997). While the two-storey housing areas in the outskirts became the residence of Qataris as well as high-income guest workers, the central areas became the residence of foreign labour. This led to a reduction in investments and subsequently to deterioration in urban qualities in Doha's centre, which became to a large extent a monotonous agglomeration of multi-storey apartment and office blocks as well as low-rise commercial buildings.

At the same time that many areas within the city centre were deteriorating, Dafnah, which stretches along the Corniche, became the new focal point of investment, with government buildings being erected there as modern landmarks and Doha's first public spaces created in the form of a park and promenade. In 1969 Government House was built on reclaimed land in the east of the market area, followed by Qatar National Bank and the Ministry of Foreign Affairs. The most significant landmark of that time was Diwan Al Amiri, completed in 1972, which replaced Government House as the official seat of the Emir and his government. The Diwan was constructed 
Figure 5. Doha Sheraton hotel introduced a new standard of modern architecture in the city while generating urban spaces along the waterfront. Source: Abeer Hasanin.

Figure 6. Qatar's Post Office; an example of state public buildings introduced in the 1980s. Source: Abeer Hasanin.
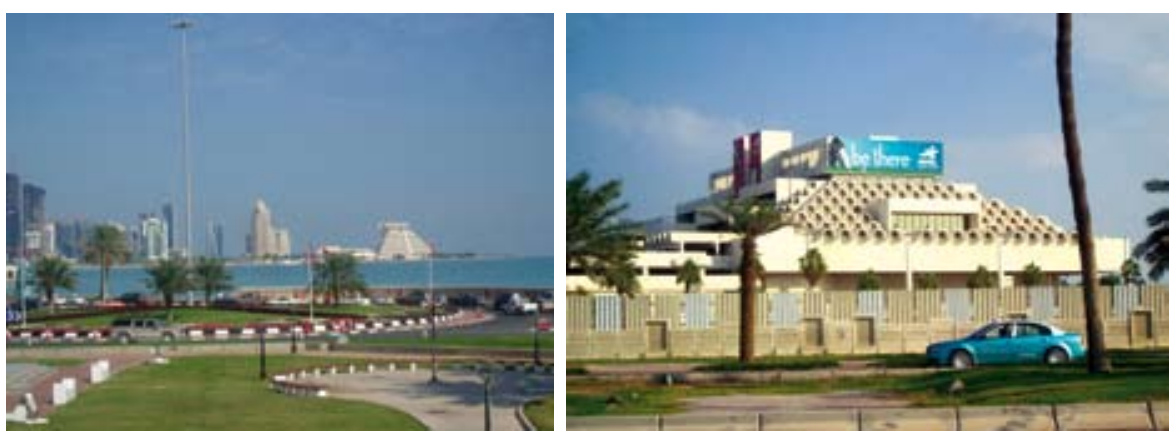

in a prominent location at the point where the Corniche begins and the old centre in the west ends. To its west the Grand Mosque and the Clock Tower were built to complete a modern architectural ensemble intended to represent Qatar's independence as well as indicate a clear cut with Doha's historic style of building. In 1983 a hotel and conference centre was developed at the northern end of the Corniche as an additional landmark and pioneering project of the NDOD development. The 15-storey hotel with its pyramid shape introduced a new standard of modern architecture in Doha (Figure 5). Together with the Al Jaidah office tower it was the tallest building structure in Doha until the 1990s (Adham, 2008, 230) and other state public buildings were introduced (Figure 6).

Doha's transformation from an 'absolute space' to an 'abstract space' was sudden and as precipitous as the oil boom that instigated it. The

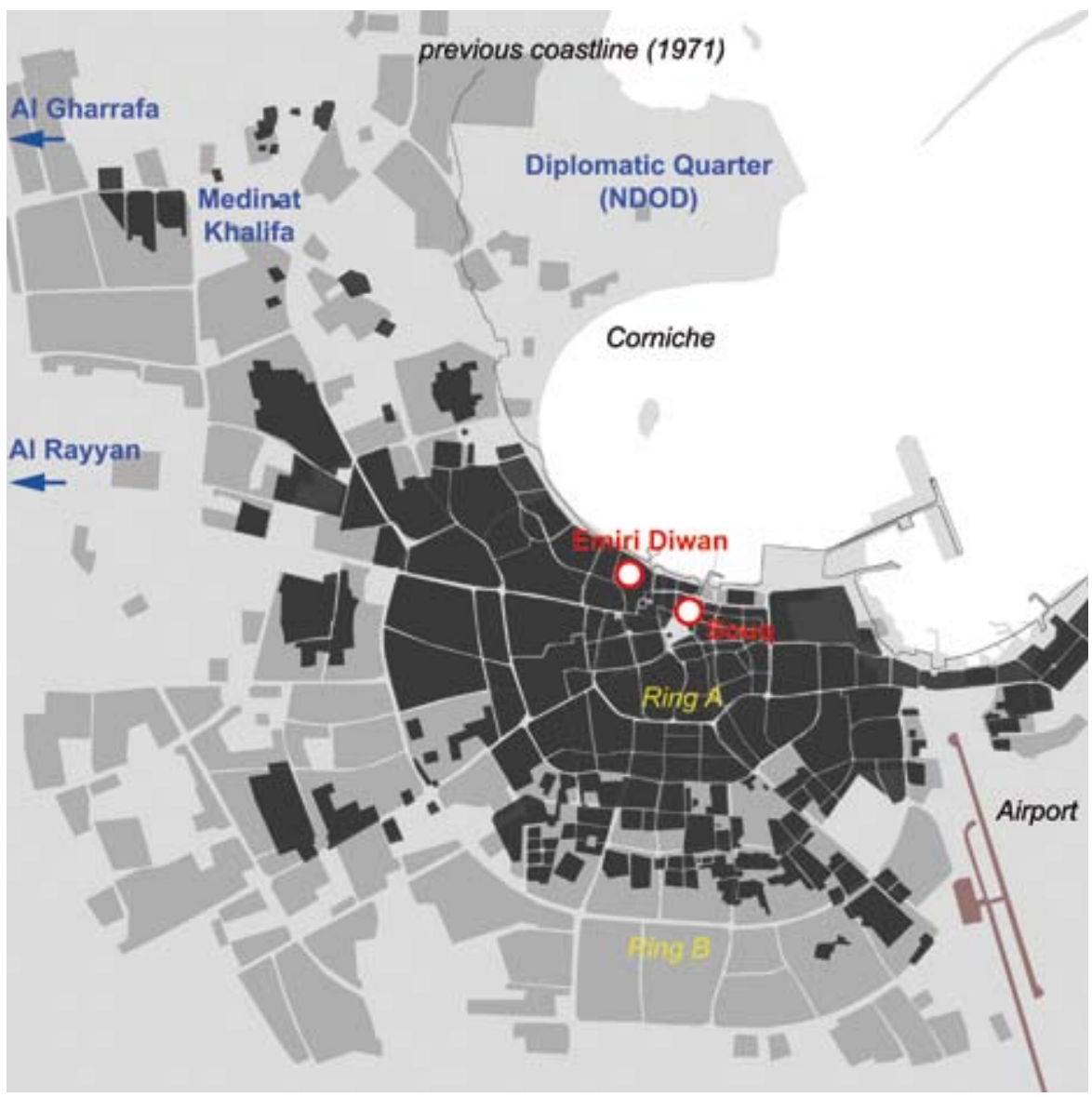


modernisation of the city was rapidly and simply executed by importing the expertise and labour necessary. This transition to modernity was reflected in the architecture and urban design of the period, which broke away abruptly from the vernacular to principles imposed by the state. This can be seen best in the replacement of the traditional neighbourhoods of the indigenous population, consisting of courtyard houses and winding streets, with modern suburban dwellings that stood on equally sized rectangular plots accessed by an orthogonal grid of roads. The Western consultants who advised this process during the post-war decades applied their Western understanding of modern space to the modernisation of Doha, which at that time considered the car to be the main means of transport. Thus, Doha developed into a car-based city incorporating geometrical grids with various road hierarchies and space for roads and parking sites, which meant the end of high densities (Figure 7).

Since the introduction of centralised governance and state planning erased the previous practice of self-governed neighbourhoods the extent of the local inhabitants' participation in urban development was reduced. Protests and resistance were, however, mediated by the introduction of welfarestate mechanisms and the subsequent tremendous rise in living standards. Within only three decades the indigenous population found itself in a new kind of city that enabled and promoted consumption on a scale never experienced before. However, while Western consumption industries entered Doha's urban space, cultural traditions were preserved in some respects, for example, by the practice of erecting large walls around dwellings in order to protect the privacy of families. The biggest impact of Qataris on the urban development though was their habit of investing in real estate rather than accumulating wealth in bank accounts or stock markets, which led to a high percentage of over $55 \%$ vacant land within the urban area in the mid-1990s (Al Buainain, 1999, 407).

\section{CONFLICTED SPACE: THE INTRODUCTION OF LIBERALISATION STRATEGIES AND THEIR IMPACT ON URBAN STRUCTURES}

Due to its enormous wealth of oil and gas Qatar's diversification process began later than that of neighbouring GCC-Gulf Cooperation Council countries. In addition to oil the world's largest gas field was discovered in the north of the Qatari Peninsula at the beginning of the 1970s. However, the production of liquefied natural gas commenced 20 years later in 1991, when Ras Laffan Industrial City was completed (Scholz, 1999, 194). Although today the export of oil and gas still accounts for over $50 \%$ of GDP there have been increasing efforts to establish new economic sectors since the mid-1990s, which have had a major impact on urban development. These attempts were mainly made possible by the transfer of power to Emir Hamad Bin Khalifa Al Thani in 1995, who initiated a number of liberalisation strategies to open Qatar up to global economic networks. The launch of Al Jazeera as a regional and international news provider in 1996 was a reinforcement of his motivation to change the international perception of Qatar from that of an oil- and gas-based welfare state to the image of a growing hub in the Gulf. Like its neighbour the emirate of Dubai, Qatar's rulership saw its biggest potential for economic diversification in its fortunate geopolitical location, which could become a transportation and service hub between Asia, Europe and Africa. However, Qatar's decentralisation and privatisation strategies have never reached the extent of Dubai's development model. Its governance has focused instead 

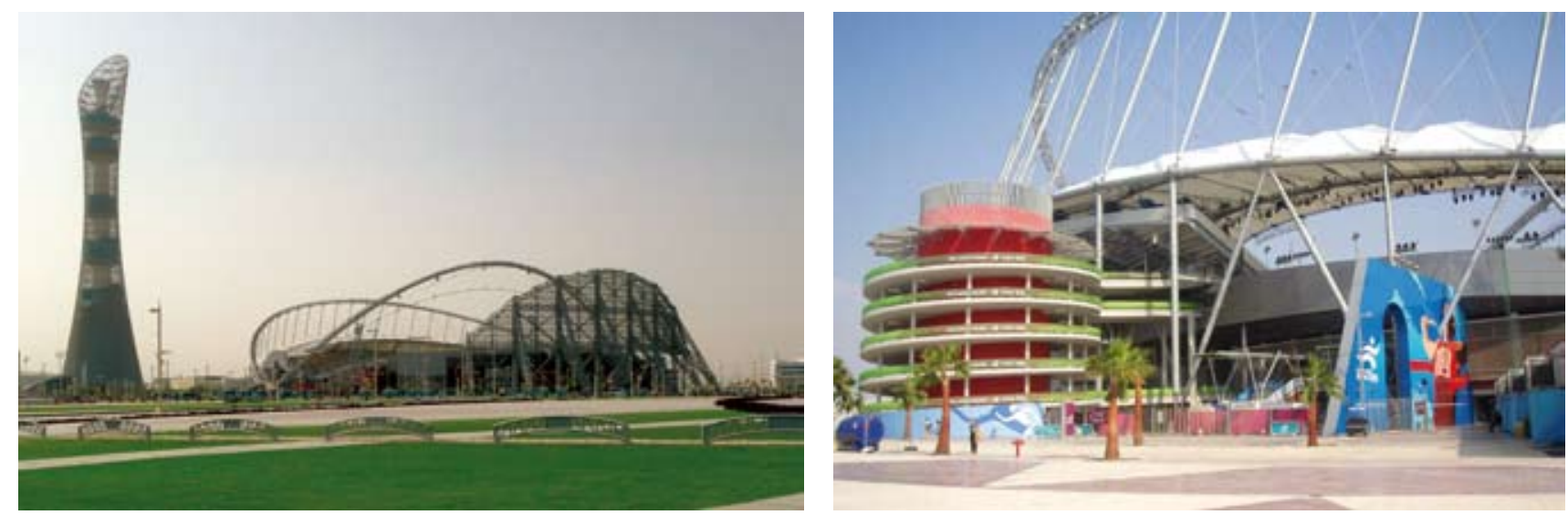

Figure 8a. Aspire Zone, a new sport city built on the peripheries of Doha. Source: Authors.

Figure 8b. Aspire Zone's Khalifa Stadium introduced to promote the city as a hub for sport events. Source: Abeer Hasanin.
Figure $9 \mathrm{a}, 9 \mathrm{~b}$. Souq Waqif, a reconstructed traditional market that introduced a new urban life in the deteriorated urban core while recalling the traditional urban fabric of Doha and promoting the city as hub for tourism. Source: Authors. on a number of key central themes as the basis for future development rather than aiming for rapid diversification by initiating growth in all directions (Adham, 2008, 248). During the late 1990s and particularly during the first decade of the new millennium the structure of Qatar's governance was made new due to the establishment of state-owned and semi-privatised institutions intended to implement the liberalisation strategy. This resulted in rapid urban growth in Doha and its metropolitan area, which grew from around 500,000 inhabitants in the late 1990s to 1.5 million in 2011 (KCIC, 2011).

Tourism was identified as a crucial factor in the establishment of Doha as an emerging hub in order to diversify the economy as well as brand the city to attract investment. Hence, there was an early focus on developing Doha as a cultural centre as well as on hosting international sports events (QSDP, 2011, 202). The success story of sports events in Qatar began with the Qatar Open and was followed by the selection of Qatar to host the 2006 Asian Games, which led to the development of the 250-hectare Aspire Zone (Hasanin, 2007) (Figure 8a, 8b). The so far biggest success of all of Qatar's sports ambitions has been the official bid for the 2022 World Cup, which was granted in 2010. Today, Qatar is an official bidding nation for the 2020 Summer Olympics and its already existing racetrack is going to be extended in order to attract Formula One. In order to host the Asian Games many new hotel developments were launched, particularly along the coast,
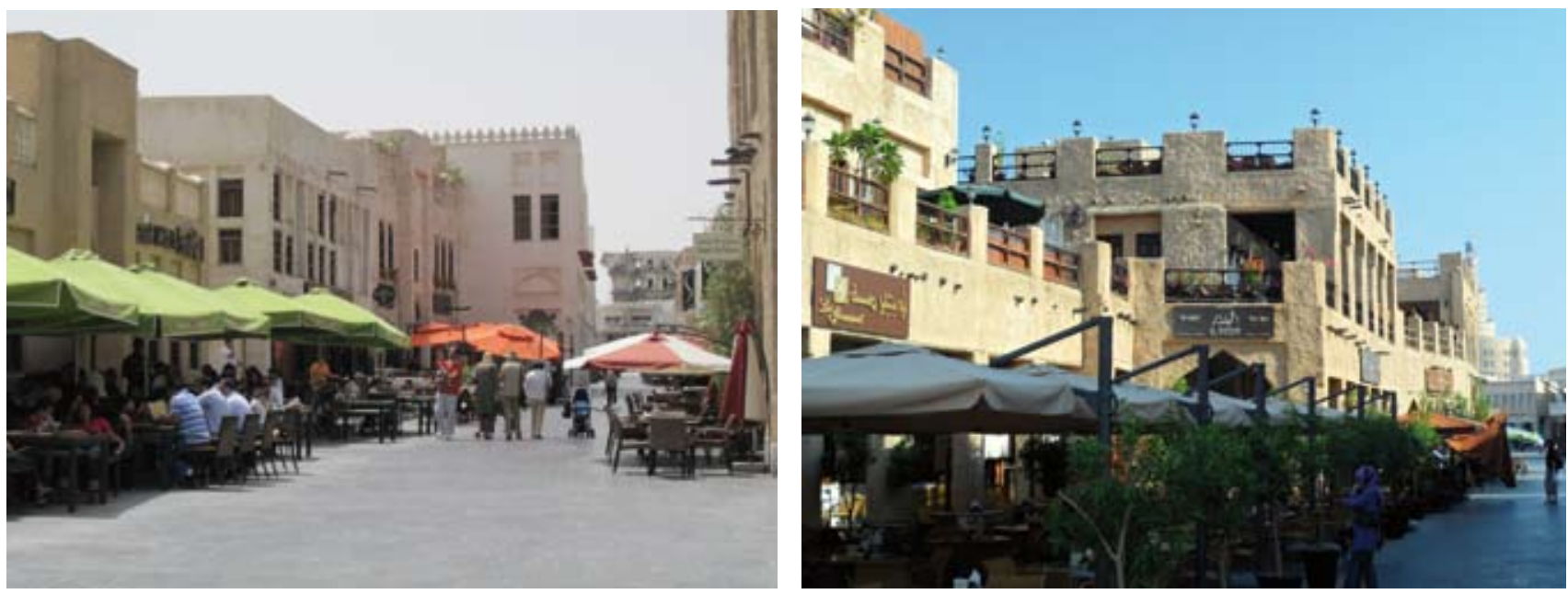


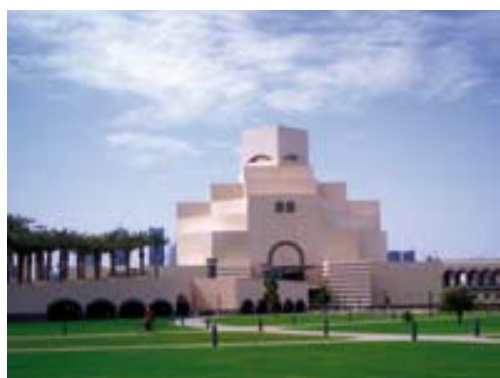

Figure 10. MIA-Museum of Islamic Arts, designed by I.M.Pei built on a reclaimed land at the old port of Doha. Source: Authors.

Figure 11a. Katara-Cultural Village devevloped on the northern coastal periphery of the city to promote cultural activities. Source: www.katara.net.

Figure 11b, 11 c. Different views of KataraCultural Village developed to foster the vision of Doha as a cultural hub. Source: Authors.

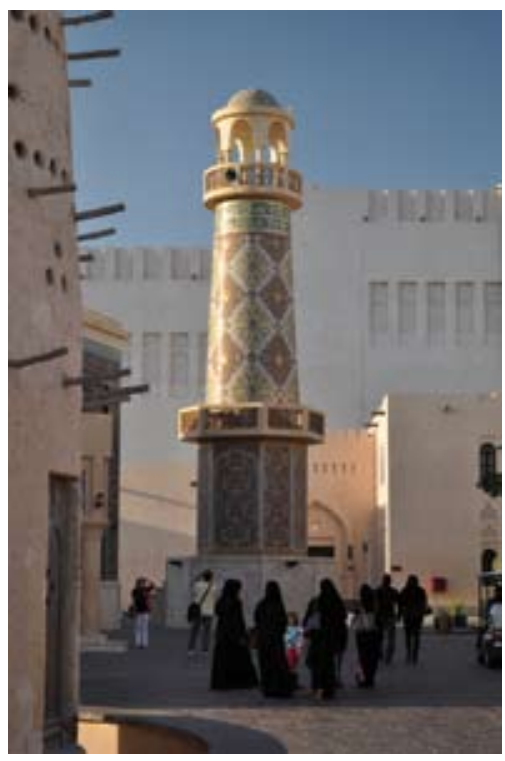

which was followed by several initiatives to revitalise Doha for visitors. Despite the fact that Doha's historic settlement was entirely replaced during the modernisation period, the country's rulers decided to establish the capital as a cultural centre in order to extend tourism beyond sports events. Subsequently, the Souq Waqif was rebuilt at its original location using traditional materials and techniques from 2004 to 2008 (Figure 9a, $9 b)$. Other cultural projects are the Islamic Museum of Art, which was completed on reclaimed land at the old port in 2008 (Figure 10), and the Cultural Village, also known as Katara, on the northern coast of the city (Figure 11a, 11b, 11c). All these developments follow the objective to attract stop-over tourists on intercontinental flights. This is expected to increase after the completion of the new airport project, whose enormous capacity of 50 million passengers by 2020 is the basis for the current strategy to establish Doha as an international hub (The Edge, 2011).
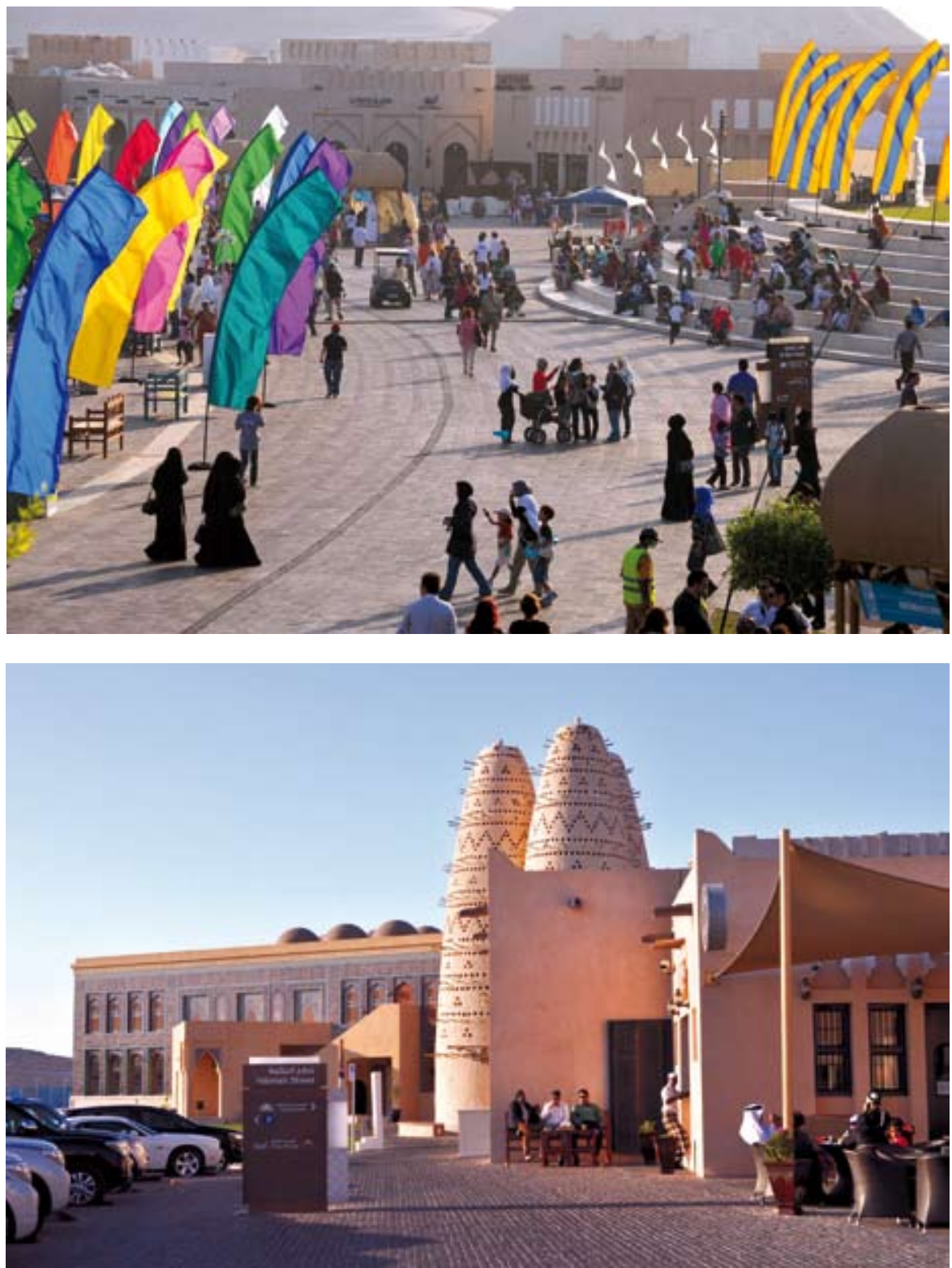
Figure 12a. Education City Master Plan: Source: QF Capital Projects.

Figure 12b. Carnegie Mellon UniversityQatar.

Figure12c. Texas A\&M University, Qatar The two buildings were designed by Legoretta and Legoretta. Source: Authors.
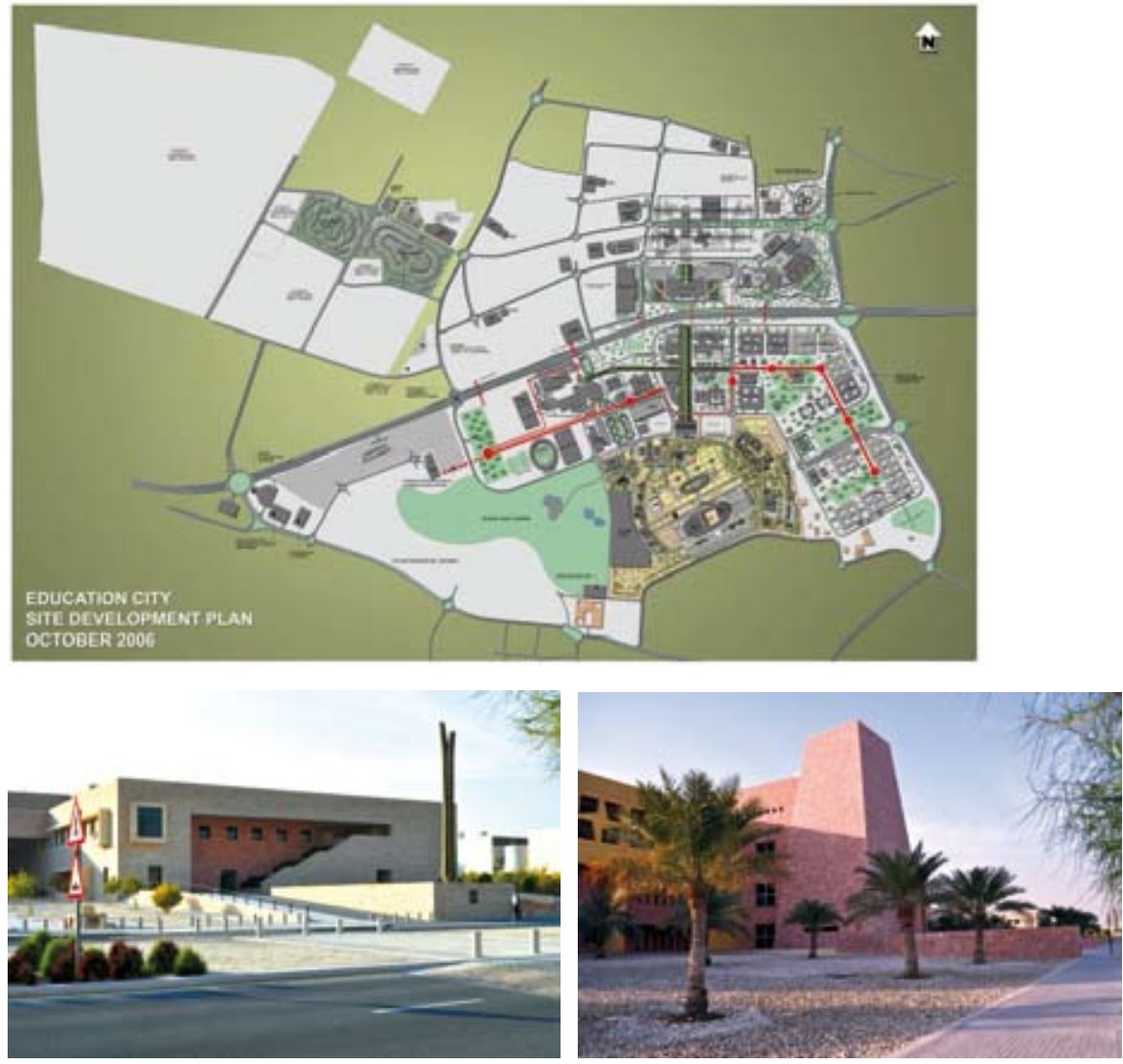

While the tourism industry was the first new oil-independent economy to be established in Qatar, there have been parallel attempts to develop Doha into a centre of knowledge economies in the region. This strategy is seen as a long-term plan and its most prominent driver is the Qatar Foundation, which was founded in 1995 as a non-profit organisation to develop a basis for new economies by focusing on three pillars, namely, education, science and community development. Its first project was Education City, the development of which was launched on an area of 2,500 acres in the northwest of the city in the late 1990s. The master plan contains educational facilities as well as residential projects and it is expected that approximately 100,000 people will reside, study or work there. Today, it is mainly an agglomeration of educational and administrative buildings that currently house five renowned American universities (Fig 12a, 12b, 12c). Science and research are promoted by its subsidiaries, the Qatar National Research Fund and the Qatar Technology and Science Park, whose taxfree environment has attracted global corporations such as EADS, GE and Microsoft. The community development aspect is being implemented in the form of social initiatives to protect Qatar's culture and heritage. The most prominent example of these is the Msheireb project, a 35-hectare mixed-use development in the south of Souq Waqif, which is intended to be a showcase example of modern Islamic architecture (Msheireb, 2011).

While the Qatar Foundation was established for the purpose of investing oil and gas revenues in the development of knowledge economies, the Qatar Investment Authority was founded in 2005 for the purpose of 
investing oil and gas surpluses in international markets as well as in local sectors such as the upcoming real-estate market. The real-estate boom in Qatar began in 2004 when the Foreign Ownership of Real Estate Law was approved, which permitted the development of freehold properties for international investors in designated areas. However, the ownership of real-estate by foreigners is restricted to renewable leasing contracts of 99 years (Colliers International, 2008, 1). In order to accommodate the increasing interest in investment in real estate, the QIA was put in charge of the Qatari Diar Real Estate Investment Company, which was founded in 2004 as a state-owned, profit-oriented developer and is responsible for real-estate projects in Qatar and abroad. It is currently in charge of the Doha Exhibition Centre, the Qatar Railways Project and a mixed-use project in Ras $\mathrm{Al}$ Khor in addition to its signature project - the Lusail City development. Lusail City is being developed on an area of $37 \mathrm{sq} \mathrm{km}$ in the north of Doha and it is expected to become home to 190,000 residents with working places for 170,000 as well as to host 90,000 additional visitors after its completion by 2025 (Qatari Diar, 2011). In addition to Qatari Diar's function of founding subsidiaries such as LREDC to carry out projects as master developer, it holds $45 \%$ of shares in Barwa, the largest listed realestate company in Qatar (Barwa, 2011).

Another important private shareholding company within Qatar's expanding real-estate market is the United Development Company (UDC), $75 \%$ of the shares of which are currently owned by Qatari investors. Its signature project is a 4 million-sq $\mathrm{m}$ reclaimed island in the south of the Lusail development, known as the Pearl Qatar. This development is designed in an iconic shape with two circular marinas and its lot area is mainly occupied by residential projects offering units in various typologies for an expected future population of 41,000 inhabitants (UDC, 2011). A further large-scale residential development is the 1.25- sq. km Waab City project in the south-west of Doha, which is being carried out by a group of Qatari investors and will offer around 2,200 housing units by 2014 (Al Waab city, 2011) (Figure 13).

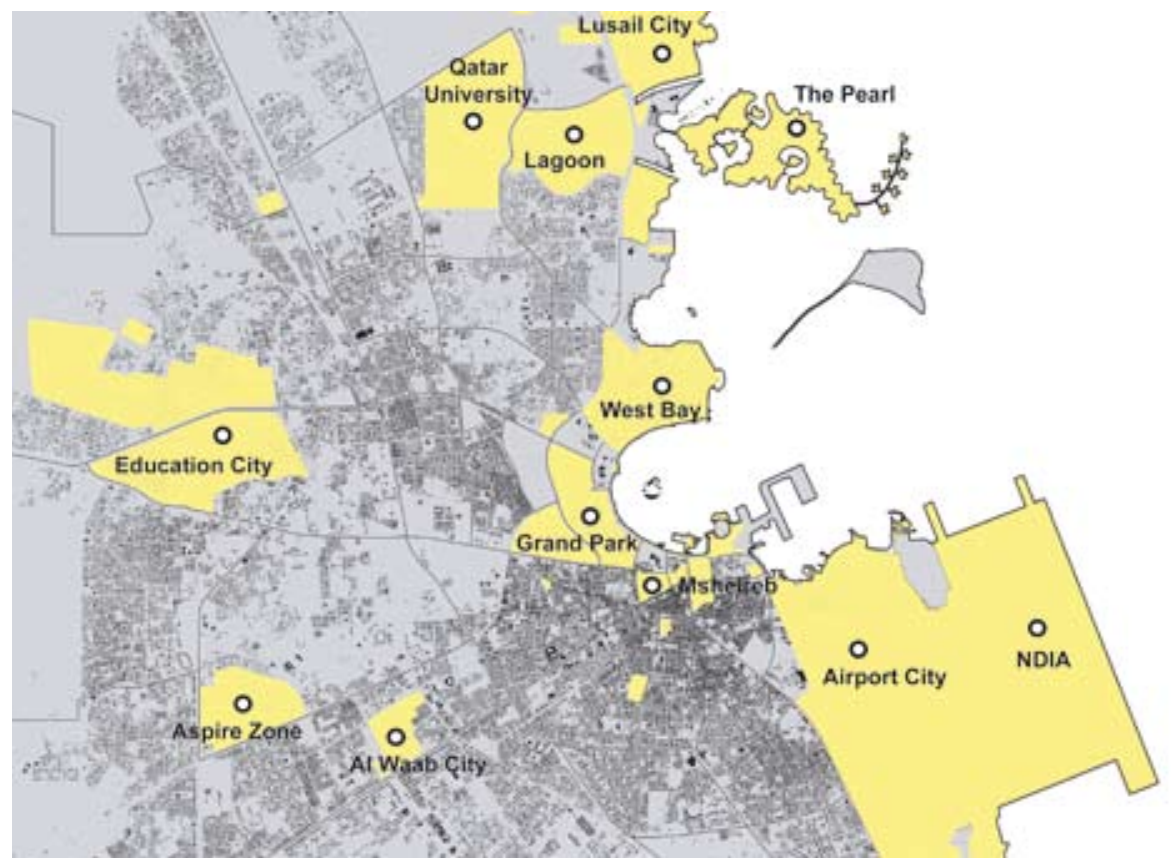


3. This was based on a number of competitions and consulting studies. One of the important studies was the Design Brief for Doha Corniche developed by INNOCENT in collaboration with the Aga Khan Trust for Culture. The document has introduced an investigation into the evolution of urban form while emphasizing the city's interface with the Bay. It is noted that in this study the Corniche was decomposed into a number of zones that reflect the unique importance of each area so that different projects can be developed in a unique manner.
Figure 14a.The emerging skyline of Doha. Source: Authors.

Figure 14b. West Bay water front highrise towers designed by international architectural firms, introduced as a reaction to the global condition while promoting the city as an international service hub. Source: Authors.
The preceding projects have commonalities; they are based on case-bycase decision-making and are thus not in accordance with the existing master plan, known as the Physical Development Plan (PDP). The PDP was prepared by the Physical Planning Department of the MMAA in cooperation with the American consultancies Louis Berger International Inc. and HOK-Helmuth, Obata \& Kassabaum Inc. in order to guide Doha's development up to 2020 (Louis Berger International, Helmuth, Obata and Kassabaum, 1997). After its implementation in 1997 it was utilized as the basis for regular zoning plans but it has had a rather limited impact on the recent projects of master developers, who have been in charge of designing their own plans, leading to a certain degree of decentralisation within urban governance. Moreover, existing zoning plans and regulations, particularly in the case of the Diplomatic District in the north of the Corniche, have been modified and adjusted to suit investors' needs (3). The Diplomatic District's prominent waterfront location and its designation for commercial land use made it attractive for the development of high-rises. During a period of less than 10 years more than 50 high-rise projects, of which 18 have a height of over 150 metres, have been built, shaping the
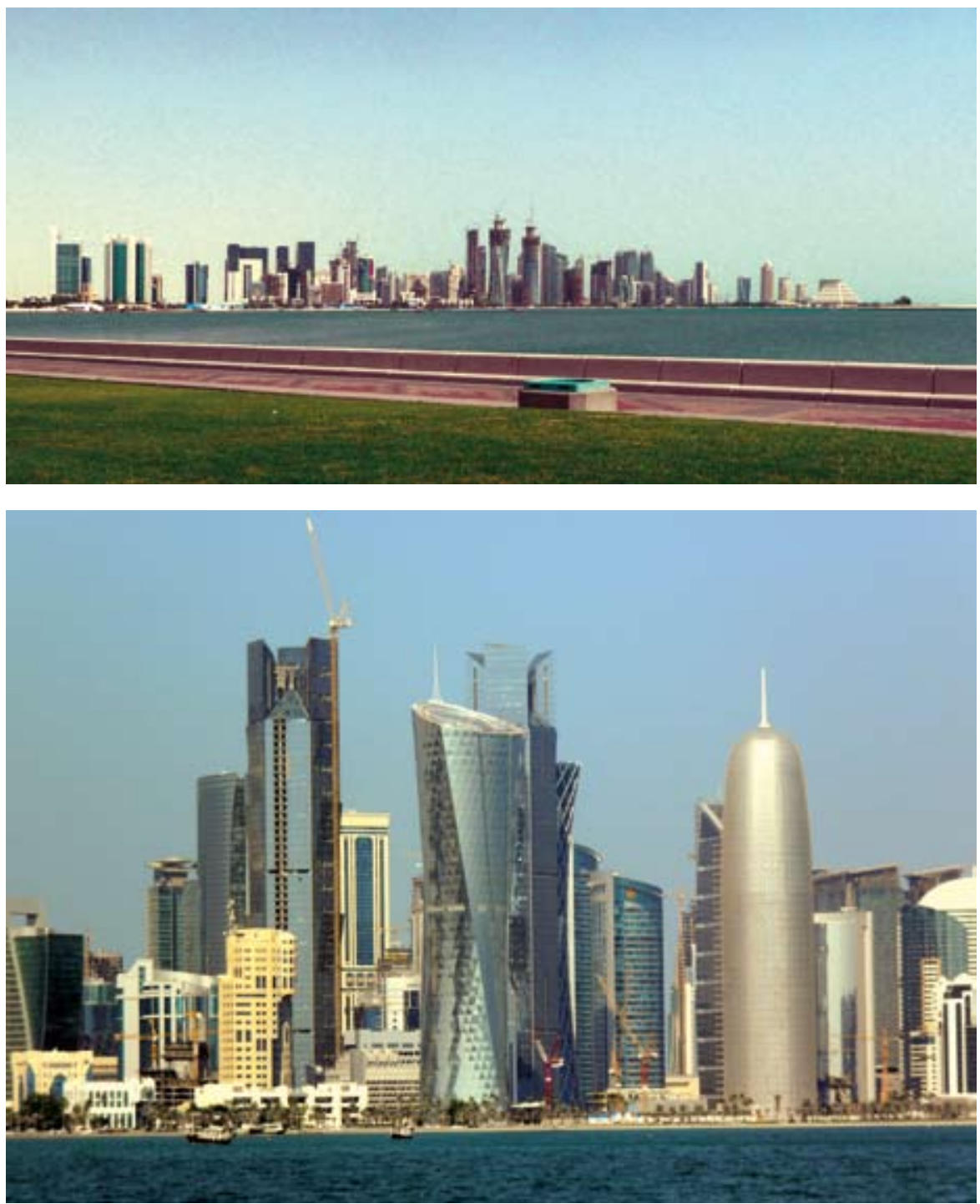
Figure 15. Doha's settlement expansion from 1947 to 2007. Source: Authors.

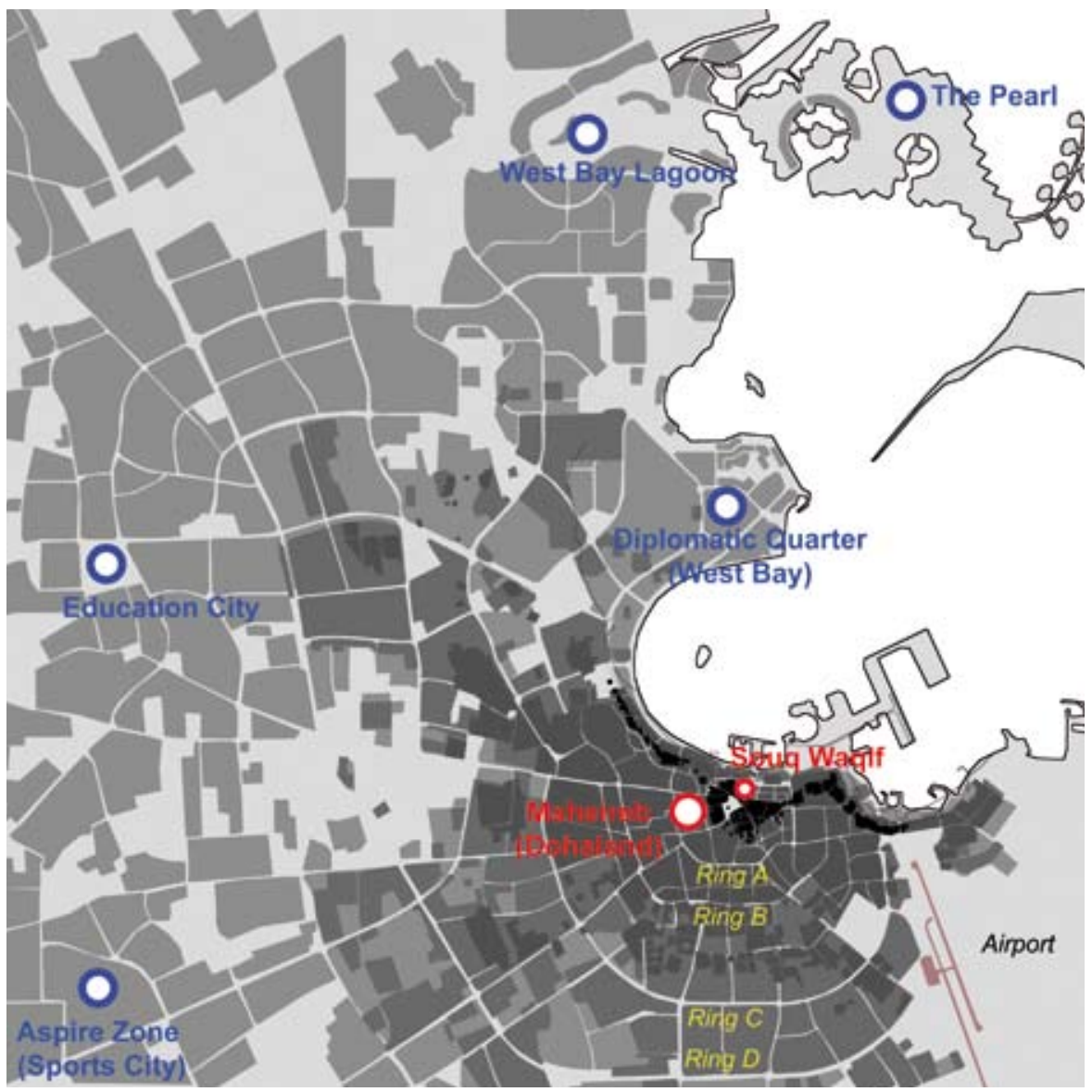

new skyline and waterfront of contemporary Doha (Figure 14a, 14b). Since 2001 City Centre, one of Doha's largest shopping malls has constituted the retail heart of the Diplomatic District, which despite its on-going development and high rate of vacancies is already being perceived as the new business centre of Doha.
Figure 16. Suburban housing area in the West Bay illustrating the severe lack of public space. Source: Authors.

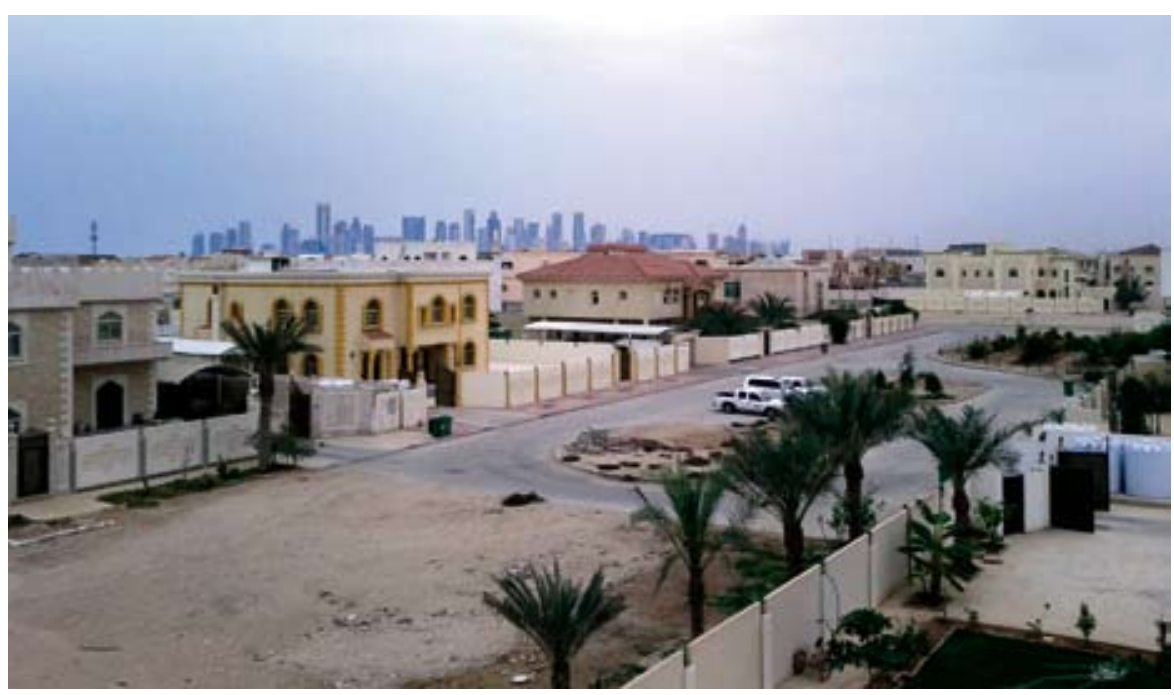


The development toward the north and the focus of investment on the waterfront has significantly changed Doha's urban structure (Figure 15). While the urbanisation period during the oil boom led to a sprawl of suburban settlements around a mixed-use centre, the more recent growth and diversification strategies have led to a phenomenon of "cities within a city" developments and a predominant emphasis on waterfront projects. Although the NDOD project was begun in the 1980s, the major urban growth to the north has been taking place over the last 20 years. Public investment in Education City and Aspire Zone was the main factor in the emergence of developments in the west of Doha such as Al Waab City. Most private sector developments however have focused on residential developments along the northern coast, for example, West Bay Lagoon, or on developments within the Diplomatic District. High land prices along the coast have led to the development of exclusive high-rise properties and thus high rental costs. Subsequently, the office market within the Diplomatic District has gradually lost pace and investment has turned its focus to residential high-rise developments. In parallel, office developments have moved to Al Sadd district at the periphery of the old centre, which has benefited from the fortunate accessibility provided by the new Doha Expressway. In general it can be stated that developments have followed the incentives of the private sector rather than any physical plan, which has led to new agglomerations with a rather low level of integrated services, causing increasing distances and thus daily traffic congestions. Doha's contemporary urban structure can be best described as fragmented without a clearly defined structure of centres and sub centres.

In addition to the transforming urban structure the new economic strategies have had a significant impact on Doha's built environment and architecture, which previously constituted a low number of typologies and landmarks. The introduction of exclusive apartment buildings for upper-income groups as well as high-rise agglomerations with unprecedented built densities have become new elements of Doha's urban landscape. Three large shopping mall complexes provided new retail centres and leisure space followed by Doha's first beach resorts and a marina promenade. Doha's architecture has developed from functional modernity and monuments representative of the state such as palaces and roundabout sculptures to a more pluralistic and post-modern design representing the space of leisure and consumption as well as global ambitions. While architectural highlights such as the Museum of Islamic Art or the Education City Convention Centre have been designed using state-of-the-art techniques, the majority of residential buildings are usually constructed with rather low-qualities and catalogue architecture. Typically, the expatriate community live in gated communities, while monotonous suburban housing is characterized by by superficial ornaments behind tall walls, resulting in a severe lack of a sense of community and the deserted urban environment (Figure 16).

Doha's current stage of urban space evolution is a product of many coinciding factors. Firstly, the change in regency that led to the introduction of a new vision for Doha's future as an emerging international hub. Secondly, the subsequent liberalisation and decentralisation process in order to accelerate urban growth. And last but not least, large public investments of oil and gas revenues into infrastructural developments as well as new city developments, carried out by state-owned institutions and their various public-private partnerships. The result has been the biggest construction boom in Doha's history driven by local, regional and 
international investors motivated by fast returns. Consequently, global companies and banks began to relocate to Doha in order to benefit from the expanding real-estate market.

While Doha has grown tremendously both vertically and horizontally, the development of technical and social infrastructure could often not keep up in speed and size. Despite the marketing of new projects as self-contained 'cities within the city' basic services have often not been integrated due to a lack of regulations. This absence of integrative development is what is mainly responsible for today's increasing traffic congestions, which are exacerbated by the non-existence of public transport. In addition, high land prices have caused living costs to rise and a lack of integrated public amenities within urban areas. While the Corniche and small parks in Doha's centre have become the last remaining public spaces in terms of a traditional definition, most spaces within new developments have been gated and branded. Moreover, the on-going social segregation is expressed in various forms and most evidently in the distribution of urban densities. While low-rise suburbs and new development areas along the coast have the lowest densities, the densities in the city centre and its periphery have rapidly increased due to the immigration of Asian labour working in lower service sectors. The missing consolidation within all the layers of Doha's urban development has led to a conflicted space representing the struggle between quantity and quality.

\section{DIFFERENTIAL SPACE: CHALLENGES FACING THE FUTURE OF DOHA'S URBANISM}

According to Lefèbvre, 'abstract space', which is mainly a product of decision-makers, will inevitably lead to conflict due to its inability to integrate the complex needs of a society (Lefèbvre, 1991). Thus, the sustainability of a city is dependent on the participation of a society that appropriates its owns space in accordance with its requirements and needs. In the city of Doha the society is still emerging and the uncertainty of its future structure has complicated the process of planning the city in a coherent manner, which depends to a large extent on a clear vision of who will live in the newly created urban environment.

Global and regional pressure on urban growth has limited the time available to explore and discuss Doha's future society, which continues to remain vague although it is undergoing a period of extraordinary expansion. Current developments are based on immigrants with temporary engagements attracted by relatively high salaries and a generally tax-free environment. Around 90\% of Doha's current population is foreign, which has a significant effect on the urban space and its qualities (Naqy, 2006, 126). Most of these foreigners are not invested in on the long-term and are thus frequently exchanged. Concomitantly, most residences are rented by companies rather than by employees, whose preferences regarding housing types and ways of living are hardly taken into account. Due to high rental prices, many exclusive developments have remained vacant and the question of who will be their residents in the future remains unanswered. In the case of labour housing, there is a current tendency to relocate these from central areas to dormitory settlements in the outskirts. The biggest example to date is Barwa's initiative to develop Barwa Al Baraha, also known as Workers' City, which is expected to house 50,000 labourers on an area of 1.8 sq. $\mathrm{km}$ at Doha`s industrial area (Barwa, 2011). 
The current attempt to develop knowledge economies as a future economic basis necessitates the emergence of a knowledge community that is capable of driving these new sectors and that is attracted to stay not only because of high wages but because of a personal long-term commitment to Doha as its choice of living and working. Thus, the needs of medium-income groups will have to gain more impact on spatial developments. Two aspects that are frequently underestimated within developing knowledge economies are the role of general urban qualities and a free choice regarding transport and housing. While Doha offers a state-of-the-art waterfront, its urban structure lacks integration of public services and amenities. In addition, the road spaces in most central and residential areas are poor in appearance and underline the perception of Doha as a fragmented city.

Despite the introduction of new residential typologies, the choice of housing for employees is currently rather limited due to the preference of many employers to sign long-term rental contracts with landlords for their staff. Furthermore, rental costs in certain developments have exceeded the limit that even medium- to high-income groups can afford or are willing to pay.

One further challenge of Doha's governance regarding its diversification strategy is the integration of the local population within the rapidly expanding public and private sectors. The first initiative was the so-called 'Strategic Qatarization Plan' in 2000, which seeks to increase the number of Qatari nationals in public institutions as well as joint ventures in the energy and industrial sectors (Strategic Qatarization Plan, 2011). The proactive integration of the local population within the new economic development is also part of the 'Qatar National Vision 2030' (QNV), which was approved in 2008 (QSDP, 2009) and is being implemented in the form of a five-year plan known as the 'Qatar National Development Strategy' (2011-2016).

The QNV was prepared under the supervision of the General Secretariat for Development Planning by various ministries. It is based on four pillars, namely human development, social development, economic development and environmental development (QSDP, 2011). While the human development strategy focuses on the particular needs of Qatar's national population such as education, health and economic participation, the social development section is concerned with the establishment of cohesiveness and consolidation within the entire society. The Ministry of Environment has been in charge of developing the environment development strategy and four ministries in cooperation with Qatar Central Bank have prepared the most extensive strategy concerning economic development. In addition, the Ministry of Municipalities and Urban Planning, which was founded after a ministerial restructuring process in 2009, has been in charge of preparing the Qatar National Master Plan (QNMP) for 2032, which was elaborated in accordance with the development aims of the QNV (Qatar Construction Sites, 2011, 15).

The QNMP is expected to be approved in 2011 and one of its main features will be the introduction of a new urban structure for Doha by directing growth toward decentralised centralisation (MMUP, 2010). The plan defines new main urban centres as well as sub-centres, which in combination with the future implementation of a multi-class and multimode transportation system will form the backbone of the future Doha (Figure 17). Based on the experience of other Gulf countries, which have published integrative master plans in recent years, the main challenge for the new master plan will be its implementation due to the need for 
Figure 17. Future centres (blue) and subcentres (green \& red) according to the QNMP. Source: Authors.

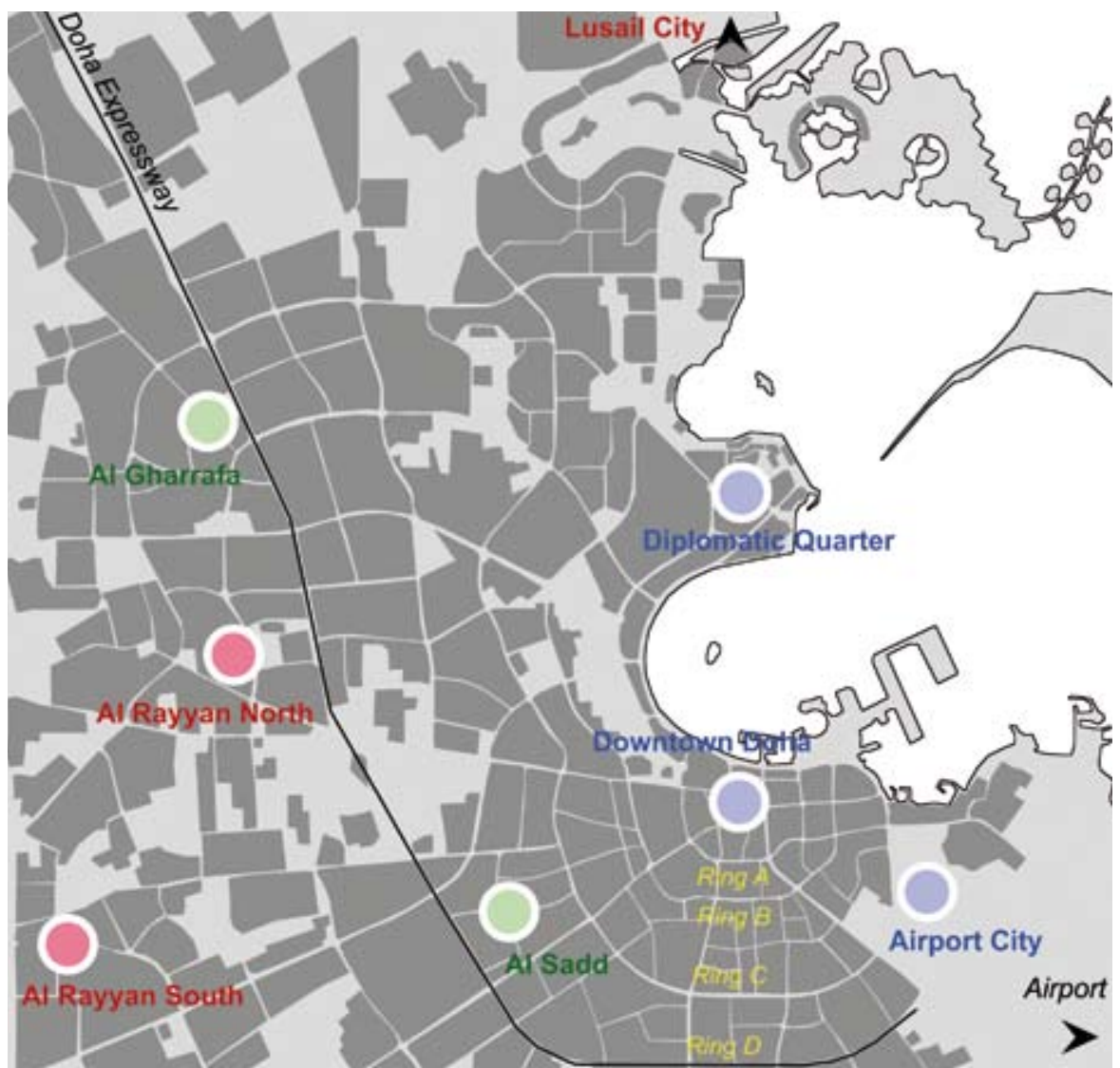

introducing strict regulations in certain areas (Wiedmann, 2010). Thus, public-private partnerships will be decisive in transforming Doha's urban structure and integrating land use as well as making transport efficient. The initiative to integrate physical planning within the wider perspective of a comprehensive development vision might mark a new chapter or phase of urbanism in Qatar. Such a phase will differ dramatically from the period of urban modernisation during the oil boom or the liberalisation policies of the last 15 years. While during the oil boom concerns were centred on developing a functioning modern city, stimulating urban growth by deregulating markets was the main concern for becoming globally and regionally competitive at the end of the 1990s. Although this race is still on going the QNV and its plans are clear signs of a new attention to consolidation instead of exponential growth.

Qatar's society needs space and time to evolve and its cohesion will highly depend on an environment that provides comprehensive qualities as well as the possibility of participating in the urban development. The current focus on supporting the national population is based on urgent concerns that a high percentage might be left out because of a lack of qualifications in comparison with the international workforce. According to the QNV the Qatari population should become the key driver of future knowledge economies by 2030 with the proportion of foreign immigrants decreasing. However, economic diversification and the establishment of Doha within global networks will always depend on expatriates with extensive experience. Thus, it will be crucial for Doha's society to become more cohesive and to integrate the needs of a qualified foreign workforce, 
Figure 18. Overview of the distinct phases within Doha's evolution of urban space. Source: Authors.

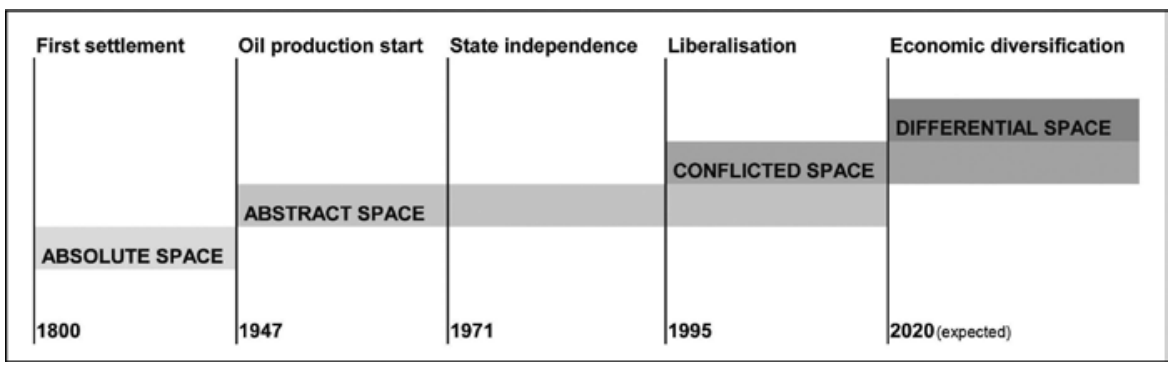

which includes property rights as well as more rights related to developing businesses.

In contrast to the previous conception of inhabitants as consumers and producers, the QNV acknowledges inhabitants as being the main asset in the knowledge and innovation needed to sustain economic growth. This will inevitably lead to the emergence of a new form of urban space, a space which incorporates the various images, preferences and faces of a diverse society and which is thus moving toward Lefebvre's definition of 'differential space'. The development of this new space, however, relies on the introduction of comprehensive urban qualities in order to attract long-term commitment and investment from qualified workforce, which constitutes the basis for the emergence of any sustainable knowledge economy. Subsequently, the evolution of urban space in Doha is facing a turning point that will lead to new spatial transformations that will shape a built environment reflecting its inhabitants rather than being an imposed urban shell containing them (Figure 18).

\section{CONCLUSIONS}

Although Lefebvre developed his theories about the evolution of space with the urban history of Europe in mind, the analysis of Doha's urbanisation utilizes general aspects of his ideas regarding the evolutionary characteristics of urban space. While in Europe the transformation process from absolute to abstract space occurred gradually over the centuries, Doha has witnessed a rapid shift from a traditional built environment to modern urban structures as a result of the oil boom and also post-colonial ties. Doha has recently begun to go through a new transformation period in which conflicts have occurred due to the increasingly fragmented and segregated nature of its urban development. These conflicted spaces are the product of privatisation and decentralisation, which caused a onesided development focus on real estate and thus an increasing lack of consolidation. These liberalisation strategies were consciously designed and introduced during the 1990s to enhance urban growth by attracting investment from the private sector. While this common growth strategy has been implemented, urban governance is facing the growing challenge of integrating urban qualities, including more effective urban structures (Figure 19).

This integration of urban qualities is becoming more and more important if economic visions of developing international service hubs are to be achieved. The successful establishment of these hubs depends on attracting highly qualified workforce for the long term. As a result, urban qualities are becoming an essential factor for Gulf economies, especially once the wealth of fossil fuels and along with it high salaries and tax free zones belong to the past. Therefore, the role of urban governance and, more specifically, 
Figure 19. Table illustrating the influence of Doha's urban governance. Source: Authors.

\begin{tabular}{|c|c|c|c|c|c|}
\hline $\begin{array}{l}\text { Lefebwre's Theory } \\
\text { on Space Evolution }\end{array}$ & $\begin{array}{c}\text { Economic } \\
\text { Background }\end{array}$ & $\begin{array}{l}\text { Government } \\
\text { Strategy }\end{array}$ & Planning Strategy & $\begin{array}{c}\text { General Impact on } \\
\text { the City }\end{array}$ & $\begin{array}{l}\text { Impact on the Built } \\
\text { Environment }\end{array}$ \\
\hline Absolute Space & $\begin{array}{c}\text { Fishing \& pearl } \\
\text { trade }\end{array}$ & $\begin{array}{l}\text { Tribal governance } \\
\text { instead of modern } \\
\text { administration. } \\
\text { Bottom up } \\
\text { decision making. }\end{array}$ & $\begin{array}{l}\text { No general } \\
\text { settlement } \\
\text { planning. Minor } \\
\text { projects such as } \\
\text { markets or port } \\
\text { expansions. }\end{array}$ & $\begin{array}{l}\text { Vernacular } \\
\text { structure based on } \\
\text { traditional } \\
\text { knowledge and } \\
\text { tribal laws. }\end{array}$ & $\begin{array}{l}\text { Traditional } \\
\text { architecture and } \\
\text { typologies such } \\
\text { as the two storey } \\
\text { courtyard house. }\end{array}$ \\
\hline Abstract Space & Oil production & $\begin{array}{l}\text { Modernisation: } \\
\text { Investments into } \\
\text { infrastructure. } \\
\text { Centralised } \\
\text { decision making. }\end{array}$ & $\begin{array}{l}\text { First Master Plan } \\
\text { in the } 1970 \mathrm{~s} \text {. } \\
\text { Introduction of } \\
\text { the car as main } \\
\text { means of transport. }\end{array}$ & $\begin{array}{l}\text { Ring road system } \\
\text { and low urban } \\
\text { densities due to } \\
\text { urban sprawl. }\end{array}$ & $\begin{array}{l}\text { Low rise dwellings } \\
\text { in suburbs. Multi- } \\
\text { storey build ings in } \\
\text { the centre. }\end{array}$ \\
\hline Conflicted Space & Real estate & $\begin{array}{l}\text { Liberalisation and } \\
\text { privatisation of } \\
\text { governance. City } \\
\text { branding as future } \\
\text { hub. }\end{array}$ & $\begin{array}{l}\text { Decentralised } \\
\text { urban } \\
\text { development due } \\
\text { to master } \\
\text { developers within } \\
\text { the private sector. }\end{array}$ & $\begin{array}{l}\text { Fragmented and } \\
\text { segregated } \\
\text { structure. No clear } \\
\text { definition of } \\
\text { centres and sub- } \\
\text { centres. }\end{array}$ & $\begin{array}{l}\text { New typologies in } \\
\text { form of high rises } \\
\text { and apartment } \\
\text { blocks. Generic } \\
\text { global architecture. }\end{array}$ \\
\hline Differential Space & $\begin{array}{c}\text { International } \\
\text { service hub }\end{array}$ & $\begin{array}{l}\text { Integrative } \\
\text { development } \\
\text { strategy. } \\
\text { Investments into } \\
\text { human resources. }\end{array}$ & $\begin{array}{l}\text { Public Private } \\
\text { Partnerships in } \\
\text { both infrastructure } \\
\text { and real estate } \\
\text { developments. }\end{array}$ & $\begin{array}{l}\text { Effective structure } \\
\text { of centres and sub- } \\
\text { centres. Multi- } \\
\text { mode transport } \\
\text { systems. }\end{array}$ & $\begin{array}{l}\text { Increasing quality } \\
\text { and diversity of } \\
\text { typologies and } \\
\text { architecture. }\end{array}$ \\
\hline
\end{tabular}

urban planning needs to be redefined by strengthening the notion of developing cities for the sake of communities rather than managing cities as business ideas. Today, the decreasing liveability instigated by lowquality housing and infrastructural problems are increasing the pressure on governance to implement integrative strategies that are amenable to prevent current fragmented and segregated development trends from continuing. These attempts might mean a new turning point within governance as it reacts to the needs of a growing part of society and thus integrate more participation into urban development processes in the city of Doha and beyond.

\section{ACKNOWLEDGEMENT}

This study is developed as part of a comprehensive funded research project of the National Priorities Research Program, QNRF-Qatar National Research Fund (NPRP 09-1083-6-023).

\section{REFERENCES}

ADHAM, K. (2008) Rediscovering the Island: Doha`s Urbanity from Pearls to Spectacle, in Elsheshtawy, Y., ed., The Evolving Arab City, Routledge, New York, NY.

AL BUAINAIN, F. (1999) Urbanisation in Qatar: A Study of the Residential and Commercial Land Development in Doha City, 1970 -1997, University of Salford, Salford.

ALAWADY, K. A. (2011) Rethinking Dubai's Urbanism: Generating Sustainable Form-Based Urban Design Strategies for an Integrated Neighbourhood, Unpublished PhD Dissertation, University of Texas at Austin, Austin.

AL WAAB CITY (2011). Introduction [WWW document]. http://www. alwaabcity.com (accessed 17.11.2011). 
BARWA (2011). About us [WWW document]. http://www.barwa.com.qa/ barwa-group/about-us/our-beginning.aspx (accessed 17.11.2011).

COLLIERS INTERNATIONAL (2008) Doha Real Estate Overview [WWW document]. http://www.colliers-me.com/Files/services/3.pdf (accessed 17.11.2011).

DAR AL HANDASEH CONSULTANTS (1986) Doha Inner City Redevelopment, Drafts Report No. 1, Evaluation and Review, Ministry of Municipal Affairs and Agriculture, Doha.

GAEBE, W. (2004) Urban Räume, Eugen Stuttgart, Ulmer.

Hakim, B. (2007) Revitalizing Traditional Towns and Heritage Districts, Archnet-IJAR-International Journal of Architectural Research, 1(3); 15366.

HASAN, A. (1994). Urban Planning in Qatar, Dar Al-Oloum, Doha.

HASANIN, A. (2007) Urban Legibility and Shaping the Image of Doha. Archnet-IJAR-International Journal of Architectural Research, 1(3); 37-54.

INNOCENT-INNOVATION CENTER FOR DESIGN AND TECHNOLOGY (2003) Design Brief for Doha Corniche-Qatar's Centre for Arts and Culture, INNOCENT Ankara.

JAIDAH, I. and BOURENNANE, M. (2009) The History of Qatari Architecture, Skira, Milan.

KCIC - KUWAIT CHINA INVESTMENT COMPANY (2011) Qatar Country Profile [WWW document]. http://www.kcic-asia.com/UserFiles/ file/Products/Country Monitors/Qatar 1304586547 2011.pdf (accessed 17.11.2011).

LEFÈBVRE, H. (1991) The Production of Space, Blackwell, Oxford.

LOUIS BERGER INTERNATIONAL INC., HELLMUTH, OBATA and KASSABAUM INC. (1997) Physical Development Plan for QatarGreater Doha Master Directive Plan, Ministry of Municipal Affairs and Agriculture, Doha.

MERRIFIELD, A. (2006) Henri Lefebvre: A Critical Introduction, Routledge, London.

MINISTRY OF MUNICIPAL AFFAIRS AND AGRICULTURE (1997) Land Prices in Doha, 1976- 1996, Physical Planning Department, Annual Reports, Doha.

MMUP-MINISTRY OF MUNICIPALITY AND URBAN PLANNING (2010) Guiding Principles and Concepts for Designing Centers, MMUP-Qatar National Master Plan, Doha.

MSHEIREB (2011) Overview [WWW document], http:/ / hod.dohaland.com (accessed 17.11.2011).

NAGY, S. (1997) Social and Spatial Process: An Ethnographic Study of Housing in Qatar, University of Pennsylvania, PA, Pennsylvania.

NAGY, S. (2000) Dressing up Downtown: Urban Development and Government Public Image in Qatar, City \& Society, 12 (1) 125-47.

NAGY, S. (2006) Making Room for Migrants, Making Sense of Difference: Spatial and Ideological Expression of Social Diversity in Urban Qatar, Urban Studies Journal Limited, v:43; 119-37. 
QATAR CONSTRUCTION SITES (2011) Issue 48, Doha.

QATARI DIAR (2011) About Qatari Diar [WWW document]. http:/ / www. qataridiar.com/fla sh/index1.htm (accessed 17.11. 2011).

QSDP- QATAR GENERAL SECRETARIAT OF DEVELOPMENT PLANNING (2011) National Development Strategy 2011-2016. Gulf Publishing and Printing Company, Doha.

QSDP -QATAR GENERAL SECRETARIAT OF DEVELOPMENT PLANNING (2009) Qatar National Vision 2030. Advancing Sustainable Development, Qatar's Second Human Development Report,Gulf Publishing and Printing Company, Gulf Doha.

SALAMA, A. M. and THIERSTEIN, A. (2010) The Quality of the Urban Environment in Emerging Regional Metropolises, The Case of Doha, Qatar, National Priorities Research Program, QNRF-Qatar National Research Fund, Doha (NPRP 09-1083-6-023).

SCHOLZ, F. (1999) Die kleinen Golfstaaten, Justus Perthes Verlag Gotha $\mathrm{GmbH}$, Gotha.

SCHARFENORT, N. (2009) Urbane Visionen am Arabischen Golf. Die "PostOil-Cities" Abu Dhabi, Dubai und Sharjah, Campus-Verlag, Frankfurt/ Main.

SHIELDS, R. (1999) Lefebvre, Love and Struggle: Spatial Dialectics, Routledge, London.

STRATEGIC QATARIZATION PLAN (2011). Mission Statement [WWW document] http://www.qatarization.com.qa/ Qatarization/Qatarization.nsf/en Pages/en AboutQatarization MissionStatement (accessed 17.11.2011).

THIERSTEIN, A. and SCHEIN, E. (2008) Emerging Cities on the Arabian Peninsula: Urban Space in the Knowledge Economy Context, Archnet-IJAR-International Journal of Architectural Research, 2 (2), 178 $-95$.

THE EDGE - QATAR`S CATALYST FOR BUSINESS (2011) Volume 7, Doha.

UDC - UNITED DEVELOPMENT COMPANY (2011) Overview [WWW document] http:/ / www.udcqatar.com/English/CorporateProfile/ Pages/Overview.aspx (accessed 17.11. 2011).

WIEDMANN, F. (2010) Post-oil Urbanism in the Gulf, University of Stuttgart, Stuttgart.

WITLOX, F. and DERUDDER, B. (2007) Airline passenger flows through cities, some new evidence, in: P. Taylor, B. Derudder, P. Saey, F. Witlox, Cities in Globalisation, Routledge, London.

ZAHLAN, R. (1979) The Creation of Qatar, Croom Helm, London. 
Alınd1: 19.12.2011; Son Metin: 28.04.2012

Anahtar Sözcükler: Doha; Katar; Körfez; kentleşme; ekonomik çeșitlenme; kentsel yapı; bilişim ekonomileri.

\section{DOHA'NIN KENTSEL EVRIMMI: EKONOMIK DÖNÜŞÜMÜN KENTSEL YAPILAR ÜZERİNDEKİ ETKİSINNE BİR ÖRNEK}

Yirminci yüzyılın ikinci yarısında ilk kentleşme dönemini yaşayan Katar, bunu büyük ölçüde petrol ürünlerinin artan üretimine borçludur. Bugün ekenomisini canlandırmak ve çeşitlendirmek için giriştiği yeni kalkınma stratejileri, ikinci bir kentsel dönüşümün yaşanmasına yol açmakta.

Sonuç olarak, yirminci yüzyılın ortalarındaki küçük balıkçı köyünün bugün bölgenin de merkezi olmaya soyunan 1,5 milyon nüfuslu bir kente dönüşmesinin nedeni budur. Yazı Katar'ın başkenti Doha'nın yaşadığı kentsel dönüşümü Henri Lefèbvre'in mekan üretimi kuramına dayanarak deneysel biçimde çözümlemektedir. Yazı hem kentin yapılı çevresi hem de kentlinin yapısı üzerinde derin izler bırakan ekonomik dönüşümün farklı evrelerini incelemektedir. Yazı ayrıca, yirminci yüzyılın sonlarında özelleştirme yanlısı liberal politikalar ve kamu yatırımları sayesinde hızla büyüyen gayrimenkul sektörünün getirdiği dönüşümü de gözönünde bulundurmaktadadır. Geçerli ekonomik kalkınma sratejilerinin gelecekteki etkisini anlayabilmek için petrol öncesi yerleşimden petrol üretimine, liberal politikaların gelişmesine ve çeşitlenen ekonomik yatırım paketleri dönemine yayılan, kentin yakın geçmişteki kentleşme serüveni ve onların yansıması olan mekansal gelişme etmenleri sıralanmaktadır. Farklı evrelerin çözümlenmesi, bize, her kentleşme evresinin özel bir ekonomik ivme sonucu olduğunu, kilit roldeki yönetişim karar ve stratejilerine bağlı olduğunu, kentin yapısı ve mimarlık üzerinde tikel etkilere yolaçtığını göstermektedir. Makale, kentin evrilmesini sağlayan süreçlerin onun gelecekteki kentsel çevreyle çelişen yönlerine de 1şık tutarak, yaşanabilir bir çevre elde edilip korunması ve kentsel yaşam niteliğinin yüksek tutulması amaçlı duyarlı stratejilerin düşünülmesi ve etkin kılınması için düşünceler ortaya atarak sonlanmaktadır.

FLORIAN WIEDMANN; BArch., M.Arch, PhD.

Post-doctoral fellow at Qatar University. Graduated from the Technical University of Dresden (2003) and the University of Stuttgart (2006) with a Master's degree in Architecture and Urban Planning. After completing his Master's dissertation on the urban development of Dubai, continued his research on urbanism in the Gulf region with a PhD thesis at the University of Stuttgart (2007- 2010). In 2009, accepted a position as urban planner at the consultancy Albert Speer \& Partner in Frankfurt, where he took part in designing the strategic master plan for 6th of October City, a satellite city of Cairo, for the Egyptian Ministry of Housing.

ASHRAF M. SALAMA; BArch., M.Arch, PhD.

Chair Professor of Architecture and Founding Head of the Department of Architecture and Urban Planning at Qatar University. Is a fellow of the Higher Education Academy-FHEA and the Royal Society of the Arts-FRSA; has held permanent, tenured, and visiting positions in Egypt, Italy, Qatar, Saudi Arabia, and the United Kingdom; is the chief editor of ArchnetIJAR: International Journal of Architectural Research, collaborating editor of Open House International-OHI, editorial board member of many international journals and organizations. Has authored and co-edited six books and published over hundred articles and in the refereed international press. Current work focuses on architecture and urbanism in emerging regional metropolis of the Gulf region. asalama@gmail.com

ALAIN THIERSTEIN, BAdm., M. Econ., Ph.D.

Is full professor for spatial and territorial development at the Munich University of Technology, Department of Architecture; and senior consultant and partner with Ernst Basler Partners Ltd., Zurich, a private engineering and planning consultancy. Holds a PhD. in Economics and a master degree in Economics and Business Administration from the University of St.Gallen. Current research interests include impact of the knowledge economy on urban and mega-city regions development, sustainable regional development, innovation and regional policy as well as policy evaluation. 